\title{
Assessing groundwater recharge and transpiration in a humid northern region dominated by snowmelt using vadose-zone depth profiles
}

\author{
Lamine Boumaiza $^{{ }^{*}}$, Romain Chesnaux ${ }^{1}$, Julien Walter ${ }^{1}$ and Christine Stumpp ${ }^{2}$ \\ 1 Département des Sciences Appliquées, Université du Québec à Chicoutimi, Chicoutimi \\ (Québec) Canada \\ 2 Institute for Soil Physics and Rural Water Management, University of Natural Resources and \\ Life Sciences, Vienna, Austria \\ *corresponding author: lamine.boumaiza@uqac.ca (L. Boumaiza)
}

\begin{abstract}
Profiles of the stable isotope ratios of pore water within the vadose-zone provide fingerprints of the history of water percolation into a soil. These profiles, combined with profiles of the volumetric water content, can determine the timing and amount of water that has percolated during specific periods. This study aims to: (i) understand water percolation at two sites in Quebec (Canada) that experience thick snow coverage during the winter season; (ii) calculate groundwater recharge rates using the peak-shift method; and (iii) estimate the transpiration rate based on the water balance budget. A 7-m-deep borehole was drilled at two sites: one site is sparsely covered by vegetation (S1), while the second underlies a pine forest (S2). For all subsamples, $\delta^{18} \mathrm{O}$ and $\delta^{2} \mathrm{H}$ from the soil pore water were analyzed, volumetric water content of the cores was measured, and grain-size analyses to estimate the hydraulic properties were performed. For both boreholes, the winter-spring and summer-autumn periods were determined. Given the limited evapotranspiration occurring during the winter-spring period, recharge rates were high at both sites $(71 \%$ and $75 \%)$, while the summer-autumn period had lower recharge rates of $63 \%(\mathrm{~S} 1)$ and $41 \%(\mathrm{~S} 2)$. A transpiration rate of $0.7 \mathrm{~mm} /$ day was estimated for the pine trees covering site $\mathrm{S} 2$. This study provides new field observations for estimating recharge based on water stable isotope profiles in a humid northern region dominated by snowmelt. Moreover, it confirms the accuracy of the peak-shift method for assessing groundwater recharge and estimating transpiration.
\end{abstract}

\section{KEYWORDS}

Groundwater recharge, peak-shift method, stable isotopes, water flow, Canada 


\section{INTRODUCTION}

As the stable isotope ratios of precipitation are strongly correlated with air temperature, a distinct seasonal pattern of rainfall is found in temperate humid climates, containing a greater proportion of heavy isotopes during summer and a lower proportion of heavy isotopes in winter (Dansgaard 1964). Thoma et al. (1979) were the first to observe that the seasonal variations of hydrogen water stable isotopes $\left(\delta^{2} \mathrm{H}\right)$ present in rainfall are preserved in the unsaturated zone (Koeniger et al. 2016). Saxena (1987) successfully traced the vertical shift of soil moisture, observing a distinct seasonal variation between the lighter winter snowmelt water and the heavier summer rainfall water. Since then, the distinctive succession of peaks characterizing the stable isotope signature in soil water has been used as a marker in several studies, including assessments of groundwater recharge (McConville et al. 2001; Adomako et al. 2010), analyses of soil water movement (Gehrels et al. 1998), calculations of soil water transit times (Stewart and McDonnell 1991; Stumpp et al. 2012), and the identification of spatial/temporal soil heterogeneities (Joshi and Maulé 2000; Hendry and Wassenaar 2009; Stumpp et al. 2009). Mueller et al. (2014) used the marked variations of water oxygen stable isotopes $\left(\delta^{18} \mathrm{O}\right)$ over time to track water flow in the unsaturated zone and to estimate the importance of vertical percolation relative to lateral subsurface flow within two steep subalpine slopes. They highlighted the efficacy of integrating stable isotope analysis and its potential application to sites, where conventional equipment cannot be easily installed or where time is a limiting factor for completing the analysis of a site. Stumpp and Hendry (2012) studied the heterogeneity of glacial till in southern Saskatchewan (Canada) using $\delta^{18} \mathrm{O}$ and $\delta^{2} \mathrm{H}$. They showed that the structure of glacial till can be highly heterogeneous over short vertical and lateral distances, and that the distribution of isotopes in groundwater can be quite variable; consequently, they recommended a plan of high-resolution soil sampling (depth 
and distance). Chesnaux and Stumpp (2018) conducted high-resolution vertical soil sampling in a humid northern region of Quebec (Canada) to assess groundwater recharge. Studying $\delta^{18} \mathrm{O}$ and $\delta^{2} \mathrm{H}$, they found that water percolation was affected by a $20-\mathrm{cm}$, less permeable, horizontal preferential pathway layer that acted as an "impermeable" barrier to percolation. Consequently, the water that drained above this low-permeable barrier could not be taken into account when calculating recharge using the peak shift method. As this environmental factor was not accounted for by the method, there was an underestimation of groundwater recharge. Uncertainties in the estimates of groundwater recharge are also caused by other factors, including land use, topography, vegetation type and density, meteorological variability (e.g. atmospheric temperature, as well as amount, duration, intensity, and frequency of rainfall), and environmental and human stresses. In reality, actual groundwater recharge is likely to be spatially heterogeneous, especially in regional aquifer systems fed by vast recharge areas (Memon 1995; Kurylyk and MacQuarrie 2013; Cartwright et al. 2017; Crosbie et al. 2018). The accurate assessment of groundwater recharge remains particularly challenging as it cannot be measured directly (Bredehoeft 2007; Bakker et al. 2013). In this study, the term "possible groundwater recharge" designates the total amount of precipitation that is theoretically available to constitute the recharge, neglecting the amounts that may flow horizontally through the vadose-zone without reaching the water table.

In addition to the stable isotope dating method, various methods have been developed and used to estimate groundwater recharge at a local or regional scale (Allison et al. 1994; De Vries and Simmers 2002): based on water budget (Yeh et al. 2007; Huet et al. 2016), fluctuations in the water table (Crosbie et al. 2005; Fan et al. 2014), streamflow analysis (Lee et al. 2006; Rutledge 2007), analytical mathematical solutions (Chesnaux 2013; Chesnaux et al. 2018) and numerical modeling (Doble and Crosbie 2017; Crosbie et al. 2018). It is also possible to combine several 
approaches to improve the accuracy of the estimates of possible groundwater recharge (Sophocleous 1991; Liu et al. 2014). Use of the stable isotope dating method has recently increased as measurements of soil water stable isotopes have become more effective, and new instrumental techniques have been developed for the analysis of stable isotopes (Koeniger et al. 2016).

In this study, stable isotopes are used to date the water that has percolated through the vadosezone down to a specific depth. Seasonal signatures of stable isotopes in percolated water, combined with measurements of soil water content, are used to quantify the possible groundwater recharge (Saxena and Dressie 1984; McConville et al. 2001; Koeniger 2003). This method, called peak-shift, assumes advection-dominated transport. It thus requires a profile of pore water stable isotopes in the vadose-zone and a depth profile of soil water content (Leibundgut et al. 2009; Adomako et al. 2010; Barbecot et al. 2018; Chesnaux and Stumpp 2018). Most studies applying this peak-shift method have been undertaken in semi-arid environments, where the marked change between wet and dry seasons creates ideal conditions for observing a stable isotope peak in the vadose-zone (Koeniger et al. 2016). In contrast, the high water table observed in humid regions limits the applicability of the peak-shift method, since the vadose-zone is limited in depth. Recharge in humid northern regions is often associated with snowmelt, and understanding as well as quantifying snowmelt percolation through the vadose-zone could serve as an alternative to the peak-shift method in these humid regions. Other factors posing a challenge when estimating groundwater recharge using stable isotopes include the determination of local site effects (e.g. vegetation coverage), and the measurement of parameters relative to the water budget such as evaporation and transpiration.

This study aims to assess the possible groundwater recharge and transpiration rates in a humid northern region dominated by snowmelt, with three main objectives. Firstly, to understand the 
dynamics of water percolation through the vadose-zone at two sites that experience heavy snow accumulation during the winter. One site is sparsely covered by vegetation; the second is covered by an extensive pine forest. To achieve this objective, two boreholes were drilled into a sandy aquifer located in the Saint-Honoré area (Quebec, Canada). Soil core samples collected from the boreholes were then analyzed for physical properties, including soil water content, and grain size to estimate soil hydraulic properties. The second objective is to assess possible groundwater recharge using the peak-shift method. The investigated sites have a relatively thick vadose-zone of $7 \mathrm{~m}$, making it possible to generate stable isotope profiles over a period of one entire year of precipitation (This required depth is known for that location thanks to the study by Chesnaux and Stumpp (2018), which investigated thinner vadose-zones of 3 and 5 meters, shown to represent a shorter infiltration history equivalent to 5 and 8 months, respectively). The third objective is to assess the possible transpiration rate of pine trees by comparing the sparsely vegetated site against the pine forest site.

\section{MATERIALS AND METHODS}

\subsection{Study area and climate data}

The investigated sites, S1 and S2, are located in the Saint-Honore area of the Saguenay-Lac-StJean region (Quebec) Canada (Figure 1). The Saint-Honoré aquifer was deposited at the end of the last glaciation period, some 11,800 years before the present, at the mouth of the Valin River that flowed north to south into the post-glacial Laflamme Sea. This unconfined aquifer has a maximum depth of $50 \mathrm{~m}$ and is composed of Quaternary deposits, consisting mostly of sands with silt that overlie a Precambrian crystalline bedrock (Boumaiza 2008). The investigated sites were selected at locations that had not been previously disturbed by human activities, e.g. sand exploitation. 
Eastern Quebec has a humid climate characterized by short, hot, and humid summers, cold and snowy winters, and rainy springs and autumns. Average monthly temperatures range from $-16{ }^{\circ} \mathrm{C}$ in January to $18^{\circ} \mathrm{C}$ in July (Chesnaux and Stumpp 2018). The Saint-Honoré aquifer captures a uniformly distributed mean annual precipitation of $930 \mathrm{~mm}$. This total includes an equivalent $320 \mathrm{~mm}$ of water representing the mean annual snow accumulation. All daily climate data, consisting of minimum/maximum temperatures and precipitation (rain and snow) were obtained from the Bagotville climate station, located $25 \mathrm{~km}$ away from the sites (Government of Canada 2019). As described by Chesnaux and Stumpp (2018), most precipitation from November to March/April falls as snow. Consequently, during almost half of the year, recharge of the unconfined aquifer is minimal. Most recharge occurs in the spring, during snowmelt, when 5-6 months of accumulated snowfall suddenly becomes available for percolation. In general, the snowmelt period occurs during the months of April and May.

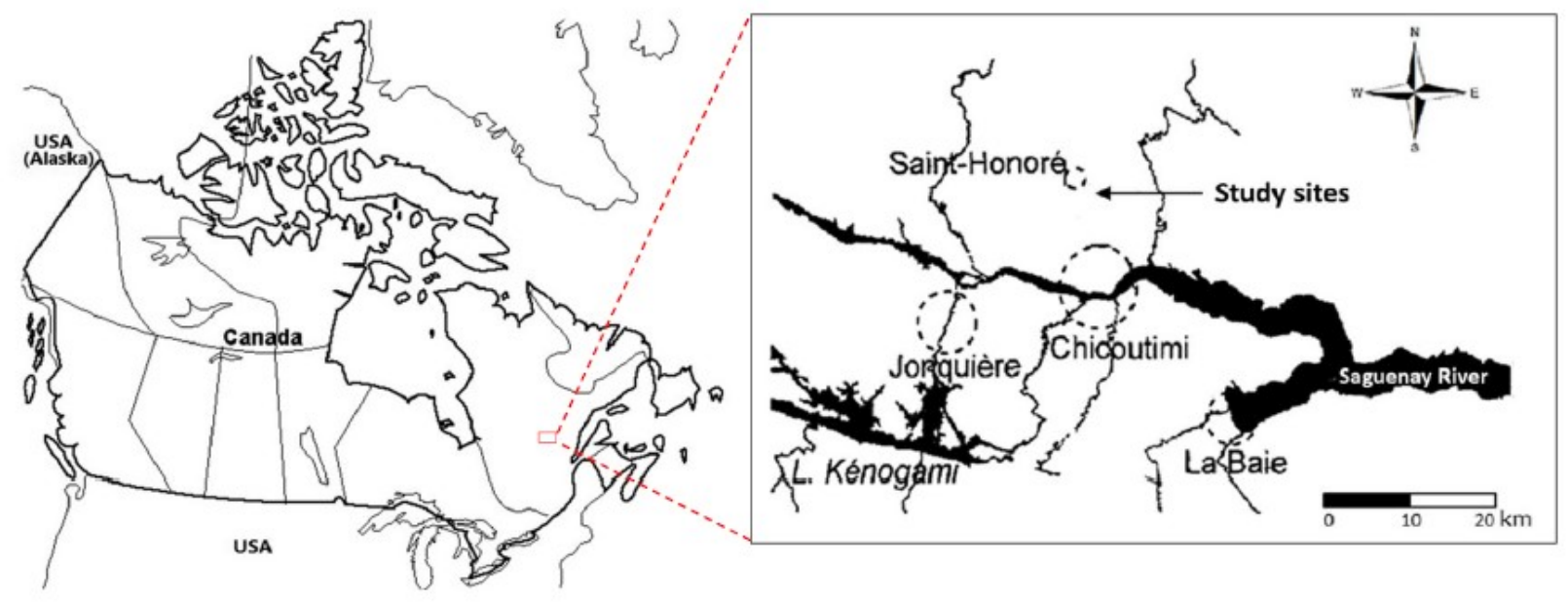

Figure 1. Location of the investigated sites 


\subsection{Stable isotope data}

As a first step, the regional water isotopic signatures of $\delta^{2} \mathrm{H}$ and $\delta^{18} \mathrm{O}$ were obtained online from a member station of the Global Network of Isotopes in Precipitation (GNIP) database, operated by the International Atomic Energy Agency (IAEA 2020). This station, called Chapais, is the closest, located approximately $350 \mathrm{~km}$ northwest of the study sites. It provides water isotope data of $\delta^{2} \mathrm{H}$ and $\delta^{18} \mathrm{O}$ only from 1997 to 2010 , and thus data is not available for the year of interest of this study, i.e., 2018, one year prior to the sampling dates of 2019 at S1 and S2. For the purposes of this study, it was assumed that the overall water isotope composition is representative of typical changes over a year, as seasonal characteristics have not changed significantly over the relevant period. This level of accuracy is sufficient because the peak-shift method relies on curve behaviours representative of seasons rather than absolute values (Chesnaux and Stumpp 2018). In

addition to GNIP data, water isotope ratios of $\delta^{2} \mathrm{H}$ and $\delta^{18} \mathrm{O}$ were obtained at a local scale from GEOTOP at the Université du Québec à Montréal, which has monitored stable isotope precipitation at the Université du Québec à Chicoutimi (UQAC). The UQAC station is located 15 $\mathrm{km}$ from the study area. Available precipitation stable isotope data from the UQAC station covers the period of July 2016 to January 2018.

\subsection{Sampling and analyses}

\subsubsection{Soil sampling}

One borehole was drilled at each study site, S1 and S2, on 23 and 24 May 2019, respectively, using a hand threshing-beating auger. Sites S1 and S2 were drilled to a depth of $7 \mathrm{~m}$ below ground surface (b.g.s.). Continuous soil cores were collected using a split-spoon sampler $0.69 \mathrm{~m}$ in length, $0.05 \mathrm{~m}$ in diameter - every $10 \mathrm{~cm}$ down-core to obtain a high-resolution 
vertical soil profile. When little soil was recovered, soil samples were collected at $15-\mathrm{cm}$ intervals. The split-spoon soil recovery percentage varied from $50 \%$ to $100 \%$; for most of the split-spoons, however, recovery was $\geq 75 \%$. The split-spoon was cleaned after the collection of each soil sample using dry towels to minimize sample cross-contamination. A total of 58 soil samples were collected from Site S1, and 54 soil samples were collected from Site S2. After an in-situ visual description (soil texture, color, humidity, etc.), the soil samples were stored immediately in separate labeled polyethylene Ziploc bags that were sealed tightly to prevent moisture loss due to evaporation. Given the humidity levels of the soil cores observed during fieldwork, the water table was assumed to be at $7 \mathrm{~m}$ b.g.s. at both sites $\mathrm{S} 1$ and $\mathrm{S} 2$.

\subsubsection{Stable isotope analyses}

The soil samples collected from the S1 and S2 boreholes were sent to the laboratory of the Institute for Soil Physics and Rural Water Management (Vienna, Austria) for analysis of the water stable isotopes $\left(\delta^{2} \mathrm{H}\right.$ and $\left.\delta^{18} \mathrm{O}\right)$. The $\delta^{2} \mathrm{H}$ and $\delta^{18} \mathrm{O}$ in the soil samples were measured using $\mathrm{H}_{2} \mathrm{O}_{\text {(liquid) }}-\mathrm{H}_{2} \mathrm{O}_{\text {(vapor) }}$ pore water equilibration and cavity ring-down laser spectroscopy. The equilibrium between the trapped water in the soil cores and the gas phase was attained after three days of sample exposure to dry air, which had been injected into the soil bags. The water vapor was then sampled continuously in the headspace using a water vapor analyzer (Picarro 20130-i). This method enables a rapid measurement of $\delta^{2} \mathrm{H}$ and $\delta^{18} \mathrm{O}$ of soil pore water from a single soil sample. A significant advantage of the laser spectroscopy soil pore water $\mathrm{H}_{2} \mathrm{O}_{\text {(liquid) }}-\mathrm{H}_{2} \mathrm{O}_{\text {(vapor) }}$ equilibration method is that pore water samples can be measured with minimal handling and exposure to evaporation (Wassenaar et al. 2008; Stumpp and Hendry 2012). Stable isotope ratios are expressed in $\delta \%$ units relative to Vienna Standard Mean Ocean Water (VSMOW). The isotope ratios are calculated using the following equation (eqn. 1): 


$$
\delta=\frac{R_{\text {sample }}-R_{\text {standard }}}{R_{\text {standard }}}
$$

where $R_{\text {sample }}$ represents either the ${ }^{18} \mathrm{O} /{ }^{16} \mathrm{O}$ or the ${ }^{2} \mathrm{H} /{ }^{1} \mathrm{H}$ ratio of the pore water sample, and $R_{\text {standard }}$ is the ${ }^{18} \mathrm{O} /{ }^{16} \mathrm{O}$ or the ${ }^{2} \mathrm{H} /{ }^{1} \mathrm{H}$ ratio of the VSMOW.

\subsubsection{Determining the soil physical properties}

\subsubsection{Soil properties determined by drying}

After the isotope analysis, a single representative soil subsample was collected from each of the core samples stored in the polyethylene Ziploc bags. Samples were collected using a specific metal cylinder of a given volume from which the total soil wet and dry soil mass were determined. After weighing, all soil subsamples were then dried for $48 \mathrm{~h}$ in an oven at a temperature of $105^{\circ} \mathrm{C}$.

The gravimetric water content $\left(\theta_{\mathrm{G}}\right)$ of each single representative soil subsample, expressed in $\%$, was determined according to eqn. (2) (Gardner 1965).

$$
\theta_{\mathrm{G}}=\frac{\text { weight of wet soil }(\mathrm{g})-\text { weight of dry soil }(\mathrm{g})}{\text { weight of dry soil }(\mathrm{g})} \cdot 100
$$

Afterwards, the dry bulk density $\left(D_{\mathrm{b}}\right)$, expressed in $\mathrm{g} / \mathrm{cm}^{3}$, was determined using eqn. (3) (Black et al. 1965).

$$
D_{\mathrm{b}}=\frac{\text { weight of dry soil }(\mathrm{g})}{\text { volume of specific cylinder }\left(\mathrm{cm}^{3}\right)}
$$


Once $D_{\mathrm{b}}$ was determined, the porosity $(n)$ and the volumetric water content $\left(\theta_{\mathrm{V}}\right)$, both expressed in \%, were calculated for each subsample using eqn. (4) (Black et al. 1965) and eqn. (5) (Gardner 1965), respectively, assuming a particle density $\left(\rho_{\mathrm{p}}\right)$ of $2.69 \mathrm{~g} / \mathrm{cm}^{3}$ for sand (Boumaiza et al. 2015), and a water density $\left(\rho_{\mathrm{w}}\right)$ of $1 \mathrm{~g} / \mathrm{cm}^{3}$. The void ratio $(e)$ was calculated for each subsample using eqn. (6)

$$
\begin{gathered}
n=100 \cdot\left[\rho_{\mathrm{p}}-\left(\frac{D_{\mathrm{b}}}{\rho_{\mathrm{p}}}\right)\right] \\
\theta_{\mathrm{V}}=\theta_{\mathrm{G}} \cdot\left(D_{\mathrm{b}} / \rho_{\mathrm{w}}\right) \\
e=\frac{n}{1-n}
\end{gathered}
$$

\subsubsection{Soil properties determined by sieve grain-size analyses}

Soil characteristics, such as the texture of sediments and the shape and orientation of grains, are known to influence water flow (Anderson 1989; Eaton 2006; Boumaiza et al. 2019). In this study, a visual description of soil subsamples collected from boreholes revealed that some successive soil subsamples in the borehole had similar physical soil characteristics. Consequently, similar successive subsamples of the same borehole were combined to represent the physical soil characteristics for a certain depth interval. This grouping approach is common in hydrogeology studies, i.e. soil units that are characterized by a similar class, such as sand, and a similar grainsize fraction, such as fine-grained, are grouped into one representative unit (Zappa et al. 2006; Boumaiza et al. 2017, 2019). Grain-size sieve analysis was performed on several combined soil subsamples, generating representative grain-size curves. The Wentworth classification 
(Wentworth 1922) was used for unconsolidated sediments (clay: $<0.003 \mathrm{~mm}$, silt: $0.003-0.06$ $\mathrm{mm}$, sand: $0.06-2 \mathrm{~mm}$, gravel: $2-64 \mathrm{~mm}$ ). These grain-size curves were used to predict the saturated hydraulic conductivity $\left(K_{\mathrm{s}}\right)$.

Ever since Seelheim (1880) proposed that $K_{\mathrm{s}}$ should be related to the squared value of pore diameter, many predictive equations for $K_{\mathrm{s}}$ have been proposed (Chapuis 2012). In this study, five empirical equations were selected to determine $K_{\mathrm{s}}$ : Hazen (1892), Beyer (1964), Chapuis (2004), Sauerbrey (1932), and USBR (Vukovic and Soro 1992). Table 1 summarizes these selected empirical equations with their characteristics, including: (i) the type of soil for which they were proposed; (ii) the use of the effective grain size $\left(d_{\mathrm{x}}\right)$ as the size such that $x(\%)$ of the solid soil mass is composed of grains finer than $d_{\mathrm{x}}$; (iii) the use of porosity $(n)$ or void ratio $(e)$; and (vi) the limitations of applicability related to the coefficient of uniformity for non-plastic soils $\left(C_{\mathrm{u}}=d_{10} / d_{60}\right)$, the effective grain size $d_{10}$, the nature of the soils, and the value of void ratio. Given the different capabilities and limitations of each these empirical equations, as presented in Table 1, some equations may not be applicable to certain soil samples. Thus, a $K_{\mathrm{s}}$ value was calculated for each soil sample by using several applicable empirical equations among the five available, and then calculating a single average $K_{\mathrm{s}}$ value for each soil sample, representing the geometric mean value (Zappa et al. 2006). In addition, an equivalent saturated hydraulic conductivity value, $K_{\text {s.eq, }}$, for the vertical soil profile at each sampling site was determined as a harmonic mean value of the $K_{\mathrm{s}}$ values, because the flow during the percolation is considered to be predominantly vertical (Freeze and Cherry 1979). 
Table 1. Selected empirical methods used to predict $K_{\mathrm{s}}$ with their conditions of application.

\begin{tabular}{|c|l|l|}
\hline Method & \multicolumn{1}{|c|}{ Empirical formula } & \multicolumn{1}{c|}{ Conditions } \\
\hline Hazen & $K(\mathrm{~cm} / \mathrm{s})=\left(d_{10}\right)^{2}$ & $\begin{array}{l}\text { a. Sand and gravel } \\
\text { b. } C_{\mathrm{u}} \leq 5 \\
\text { c. } 0.1 \mathrm{~mm} \leq d_{10} \leq 3 \mathrm{~mm}\end{array}$ \\
\hline Chapuis & $\left.K(\mathrm{~cm} / \mathrm{s})=2.4622\left(\left(d_{10}\right)^{2} e^{3}\right) /(1+e)\right)^{0.7825}$ & $\begin{array}{l}\text { a. All natural soils without plasticity } \\
\text { b. } 0.003 \mathrm{~mm} \leq d_{10} \leq 3 \mathrm{~mm} \\
\text { c. } 0.3 \leq e \leq 1\end{array}$ \\
\hline Beyer & $K(\mathrm{~cm} / \mathrm{s})=0.45\left(d_{10}\right)^{2} \log \left(500 / C_{\mathrm{u}}\right)$ & $\begin{array}{l}\text { a. } \text { Sand } \\
\text { b. } 0.06 \mathrm{~mm} \leq d_{10} \leq 0.6 \mathrm{~mm} \\
\text { c. } 1 \leq C_{\mathrm{u}} \leq 20\end{array}$ \\
& & $\begin{array}{l}\text { a. Sand and silty sand } \\
\text { b. } d_{10} \leq 0.5 \mathrm{~mm}\end{array}$ \\
\hline Sauerbrey & $K(\mathrm{~cm} / \mathrm{s})=2.436 \mathrm{n}^{3}\left(d_{17}\right)^{2} /(1-n)^{2}$ & $\begin{array}{l}\text { a. Sand and gravel } \\
\text { b. } C_{\mathrm{u}} \leq 5\end{array}$ \\
\hline USBR & $K(\mathrm{~cm} / \mathrm{s})=0.36\left(d_{20}\right)^{2.3}$ & \\
\hline
\end{tabular}

\subsection{Calculation of possible groundwater recharge}

As the isotopic composition of precipitation varies seasonally, the isotopic signature of a specific percolation period can be determined using the pore water stable isotope depth profile. The challenge here is to estimate possible groundwater recharge based on the identified seasons. This can be quantified by calculating the displaced pore water volume through the vadose-zone over a specific period. The peak-shift method (Saxena and Dressie 1984; Leibundgut et al. 2009) can be applied for this purpose; the amount of stored water in the soil pores is calculated using the $\theta_{\mathrm{V}}$ vadose-zone profiles. The peak-shift method considers only vertical water percolation with "no recharge loss" of infiltrated water in the horizontal direction. It also considers that dispersion is negligible and consequently assumes that the infiltrated water is displaced by advection (Leibundgut et al. 2009; Adomako et al. 2010; Stumpp and Hendry 2012; Chesnaux and Stumpp 2018). In the present study, the pores of the vadose-zone are considered to be filled with water that percolates only vertically in the vadose-zone, with no percolating water along another flow direction (such as a horizontal drainage). Such assumption considers that there is no presence of less permeable material (e.g., clay) that could act as a barrier to vertical infiltration in the 
investigated vadose-zones. The estimation of possible groundwater recharge in this study takes into account the residual volumetric water content $\left(\theta_{\mathrm{r}}\right)$. Water percolation according to the pistonflow model is equivalent to the difference between $\theta_{\mathrm{V}}$ and $\theta_{\mathrm{r}}$ over a certain distance of percolation, because the water fraction $\theta_{\mathrm{r}}$ does not ultimately contribute to possible groundwater recharge (eqn. 7).

$$
R_{\mathrm{T}}=\frac{1}{T} \int_{Z_{\mathrm{t}}}^{z_{\mathrm{t}}+T}\left(\theta(z)-\theta_{\mathrm{r}}\right) \mathrm{d} z
$$

where $T$ is the period for which possible groundwater recharge is calculated $[\mathrm{T}] ; R_{\mathrm{T}}$ is the possible groundwater recharge during period $\mathrm{T}[\mathrm{L} / \mathrm{T}] ; z_{\mathrm{t}}$ represents the elevation of the infiltrated water at the starting time $t$ of the time period [L]; and $z_{\mathrm{t}+\mathrm{T}}$ is the elevation of the infiltrated water at time $t+T[\mathrm{~L}]$. Finally, $\theta(z)$ is the volumetric water content at elevation $z$, and $\theta_{\mathrm{r}}$ is the residual water content at elevation $z$.

The elevations $z_{\mathrm{t}}$ and $z_{\mathrm{t}}+T$, as well as the different elevations $z$, invoked for the calculations of $\theta_{\mathrm{V}}$ and $\theta_{\mathrm{r}}$ at various depths, are considered to be the soil depths b.g.s. in the vadose-zone of the aquifer at times $t$ and $T$. Given that the equation of the profile of $\theta_{\mathrm{V}}$ in the vadose-zone is not continuously known, the curve of the measured profile of $\theta_{\mathrm{V}}$ can be integrated over the soil subsampling intervals whose length is $z_{\mathrm{i}}+1-z_{\mathrm{i}}$. Consequently, eqn. (7) can be simplified as eqn. (8), where $m$ is the number of depth intervals that are representative of the water percolation occurring during the period $T$ for which the possible groundwater recharge is calculated (Chesnaux and Stumpp 2018):

$$
R_{\mathrm{T}}=\frac{1}{T} \int_{i=0}^{m}\left(\theta_{\mathrm{zi}}-\theta_{\mathrm{r}}\right) \cdot\left(z_{\mathrm{i}+1}-z_{\mathrm{i}}\right) .
$$


In this study, two main periods for possible groundwater recharge are established: (1) "winterspring period" lasting from November to May, and (2) "summer-autumn period" lasting from June to October.

\section{RESULTS}

\subsection{Local and regional isotopic signatures of $\delta^{2} \mathrm{H}$ and $\delta^{18} \mathrm{O}$}

Based on the stable isotope data collected at the UQAC station, the relationship of $\delta^{2} \mathrm{H}$ versus $\delta^{18} \mathrm{O}$ was plotted (Figure 2) to determine the local meteoric water line. With relation of $\delta^{2} \mathrm{H}=$ $8.23 \delta^{18} \mathrm{O}+10.74 \%$, the local meteoric water line (LMWL) is close to the global meteoric water line, which is $\delta^{2} \mathrm{H}=8 \delta^{18} \mathrm{O}+10 \%$ (Craig 1961). Soil samples from Site S2 generally have lower isotopic ratios than those of Site S1. However, all isotope ratios from sites S1 and S2 center around LMWL, and suggest negligible evaporation relative to fractionation effects. As $\delta^{18} \mathrm{O}$ and $\delta^{2} \mathrm{H}$ are strongly correlated (Figure 2), only $\delta^{18} \mathrm{O}$ values are presented and discussed in this study, but results according to $\delta^{2} \mathrm{H}$ should follow the same distribution. In general, the mean monthly $\delta^{18} \mathrm{O}$ values of water collected at Chapais and the UQAC station show higher isotopic ratios during the summer-autumn period and lower ratios during the winter-spring period (Figure 3). 


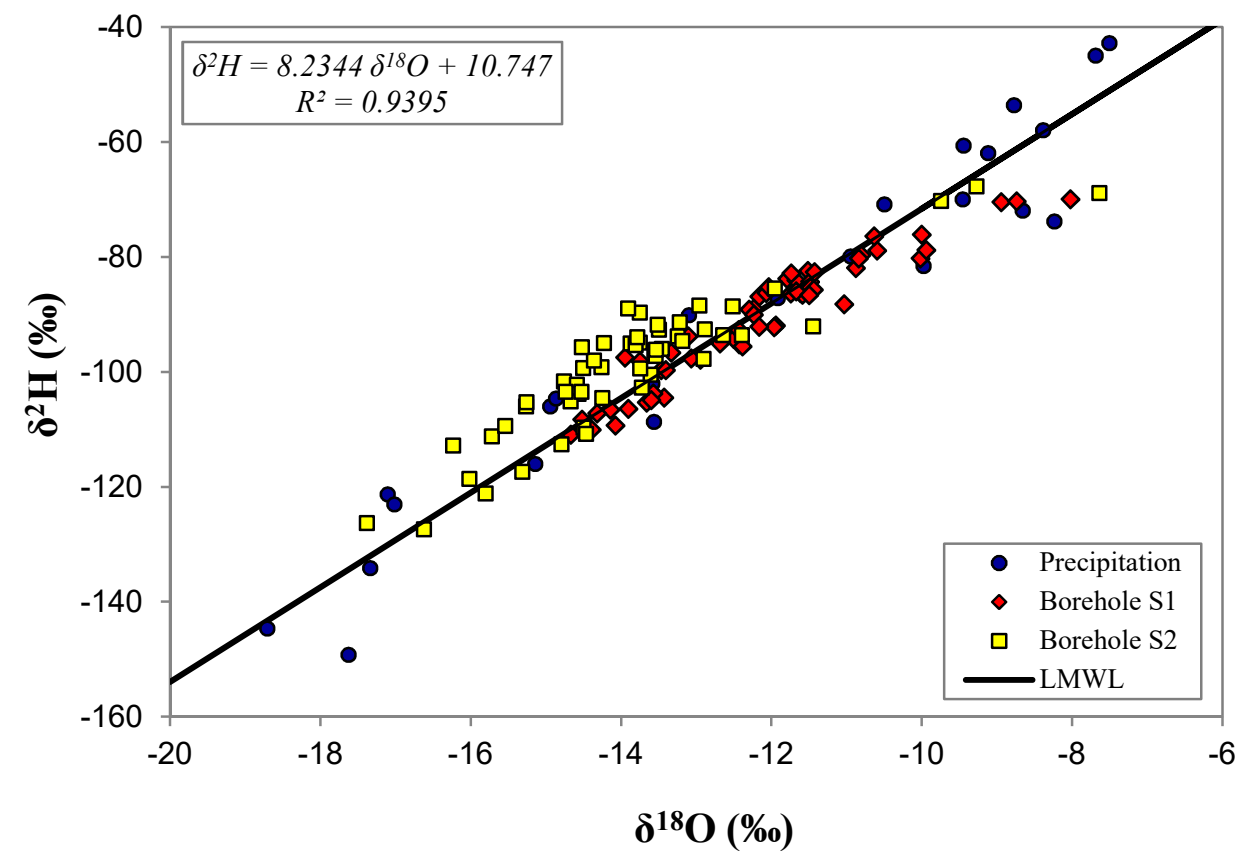

Figure 2. Precipitation isotope ratios measured at the UQAC station with the local water meteoric line (LMWL) and the water isotope ratios in the soil water at sites S1 and S2.

Variations in the isotopic composition of precipitation are mainly affected by synoptic weather patterns, such as the atmospheric conditions at the moisture source, moisture transport trajectories, and mixing between water vapor having different origins (Crawford et al. 2013; Guan et al. 2013). Consequently, the variations in the isotopic ratios provide a fingerprint of precipitation entering the subsurface and infiltrating through the vadose-zone. The winter-spring $\delta^{18} \mathrm{O}$ isotopic signature ranges from $-22 \%$ to $-12 \%$, whereas the summer-autumn $\delta^{18} \mathrm{O}$ isotopic signature generally ranges from $-12 \%$ to $-8 \%$ (Figure 3 ). These isotopic ranges can be used to identify periods of water percolation in the stable isotope profiles of the vadose-zone. 


\section{Month}

Jan. Feb. Mar. Apr. May. Jun. Jul. Aug. Sep. Oct. Nov. Dec.

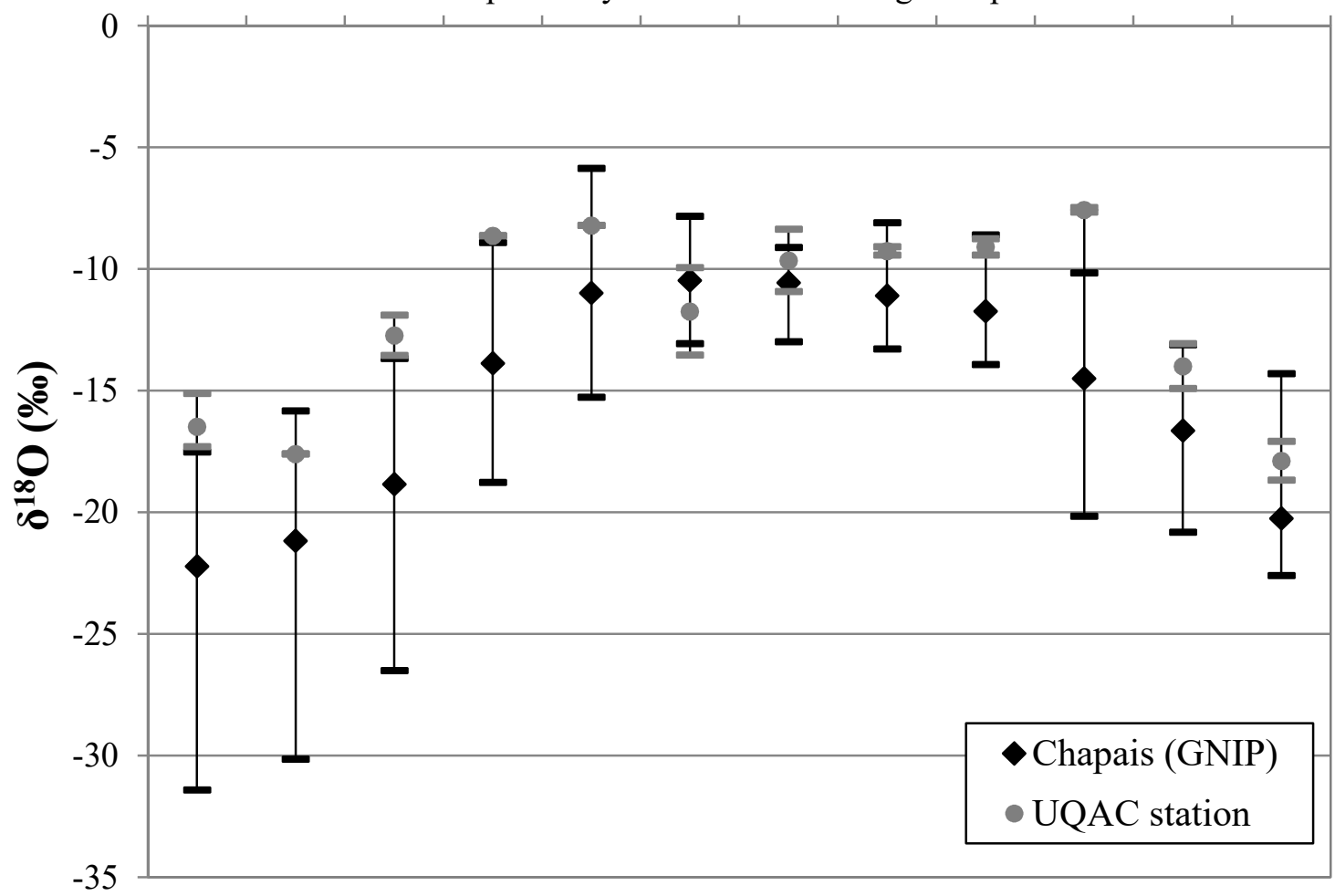

Figure 3. Monthly variation of $\delta^{18} \mathrm{O}$ in precipitation at the Chapais and UQAC stations.

\subsection{Vadose-zone stable isotope profiles}

Since the $\delta^{18} \mathrm{O}$ isotope signature of the "winter-spring period" ranges from $-22 \%$ to $-12 \%$, and that of the "summer-autumn period" generally ranges from $-12 \%$ to $-8 \%$ (Figure 3 ), the transition $\delta^{18} \mathrm{O}$ threshold value of $-12 \%$ was chosen in this study to differentiate these two time periods in the $\delta^{18} \mathrm{O}$ profiles at sites $\mathrm{S} 1$ and $\mathrm{S} 2$. The vadose-zone profiles of $\delta^{18} \mathrm{O}$ are presented in Figure 4. Since the boreholes S1 and S2 were both drilled at the end of the spring season (May 2019), it can be assumed that the top of the vadose-zone stable isotope profiles (Figures $4 \mathrm{a}$ and 4b) corresponds to the "winter-spring period". The variation of the $\delta^{18} \mathrm{O}$ ratios can be seen to correspond to that of the "winter-spring period" shown in Figure 3. The only exception to this is the top of the profiles that seem mostly impacted by the average $\delta^{18} \mathrm{O}$ isotopic signature of the 
rainfall received during the month of May. The first determined time period corresponds to depths from ground surface to $290 \mathrm{~cm}$ for Site S1, and from ground surface to $388 \mathrm{~cm}$ for Site S2. The depths of $290 \mathrm{~cm}$ and $388 \mathrm{~cm}$ correspond to the transition $\delta^{18} \mathrm{O}$ threshold value of $-12 \%$ at sites S1 and S2, respectively. Deeper $\delta^{18} \mathrm{O}$ ratios (Figures 4a and 4b) should thus be representative of the "summer-autumn period" at depths between $290 \mathrm{~cm}$ to $700 \mathrm{~cm}$ for Site S1, and $388 \mathrm{~cm}$ to $700 \mathrm{~cm}$ for $\mathrm{S} 2$. This time period is characterized by $\delta^{18} \mathrm{O}$ ratios (Figures $4 \mathrm{a}$ and $4 \mathrm{~b}$ ) that are included in the isotopic signature interval $(-12 \%$ to $-8 \%$ ) of the "summer-autumn period" shown in Figure 3. For the profile of site S2, the profiles of $\theta_{\mathrm{V}}$ as a function of depth (section 'Volumetric water content profiles') are also used to support the chosen limit separating the two time periods. Due to the presence of a snowpack and frozen surface soil acting as a barrier to percolation, the onset of winter-spring period should produce a $\theta_{\mathrm{V}}$ having no marked variations relative to that of summer-autumn period. This observation was clearly made at approximately $388 \mathrm{~cm}$ b.g.s at Site S2, supporting the chosen limit separating the two periods according to the isotope ratios. The dates corresponding to the beginning and the end of each period (Figure 4) were determined based on the temperature variations recorded at the Bagotville climate station for the year of interest (Government of Canada 2019). 


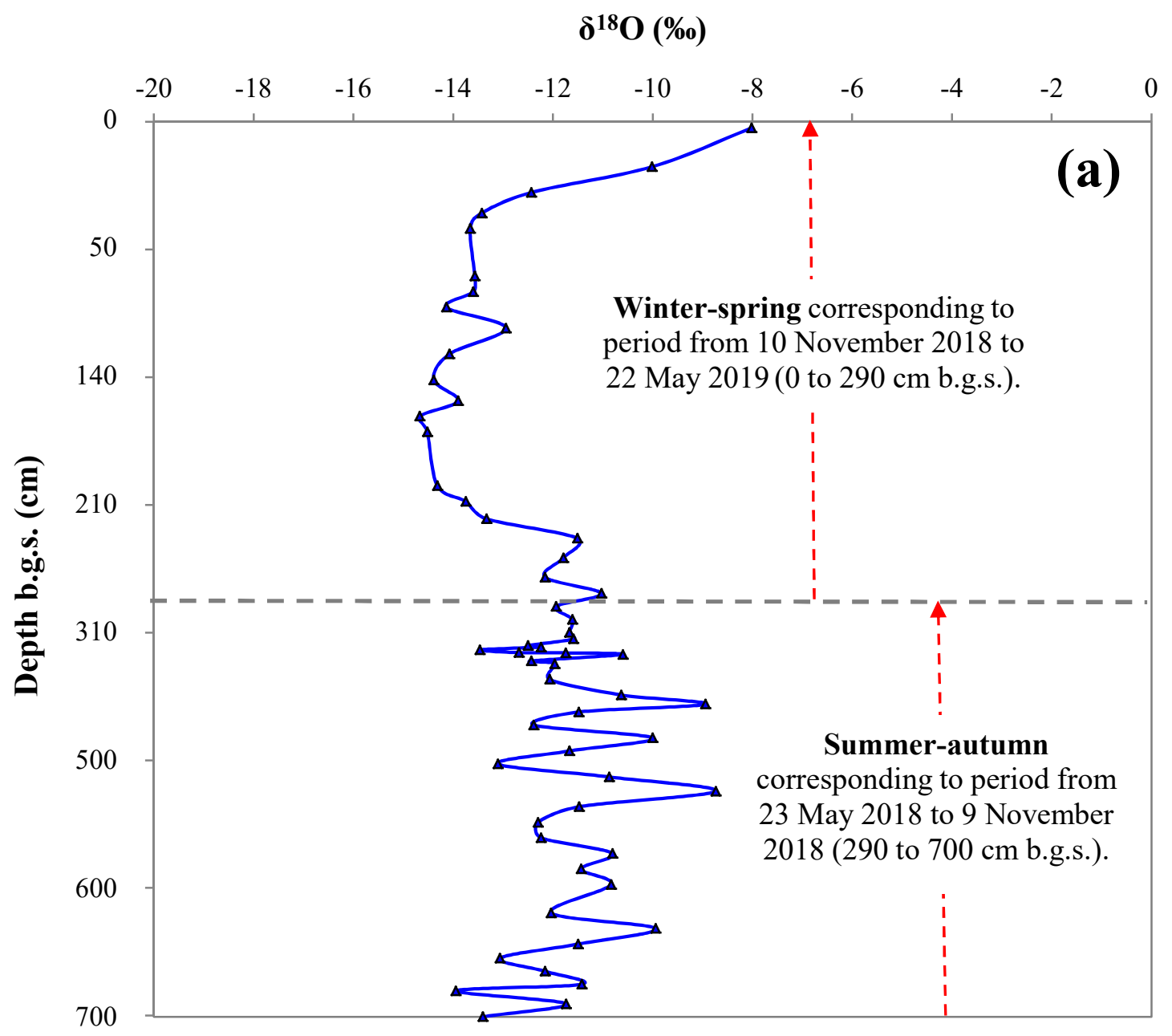




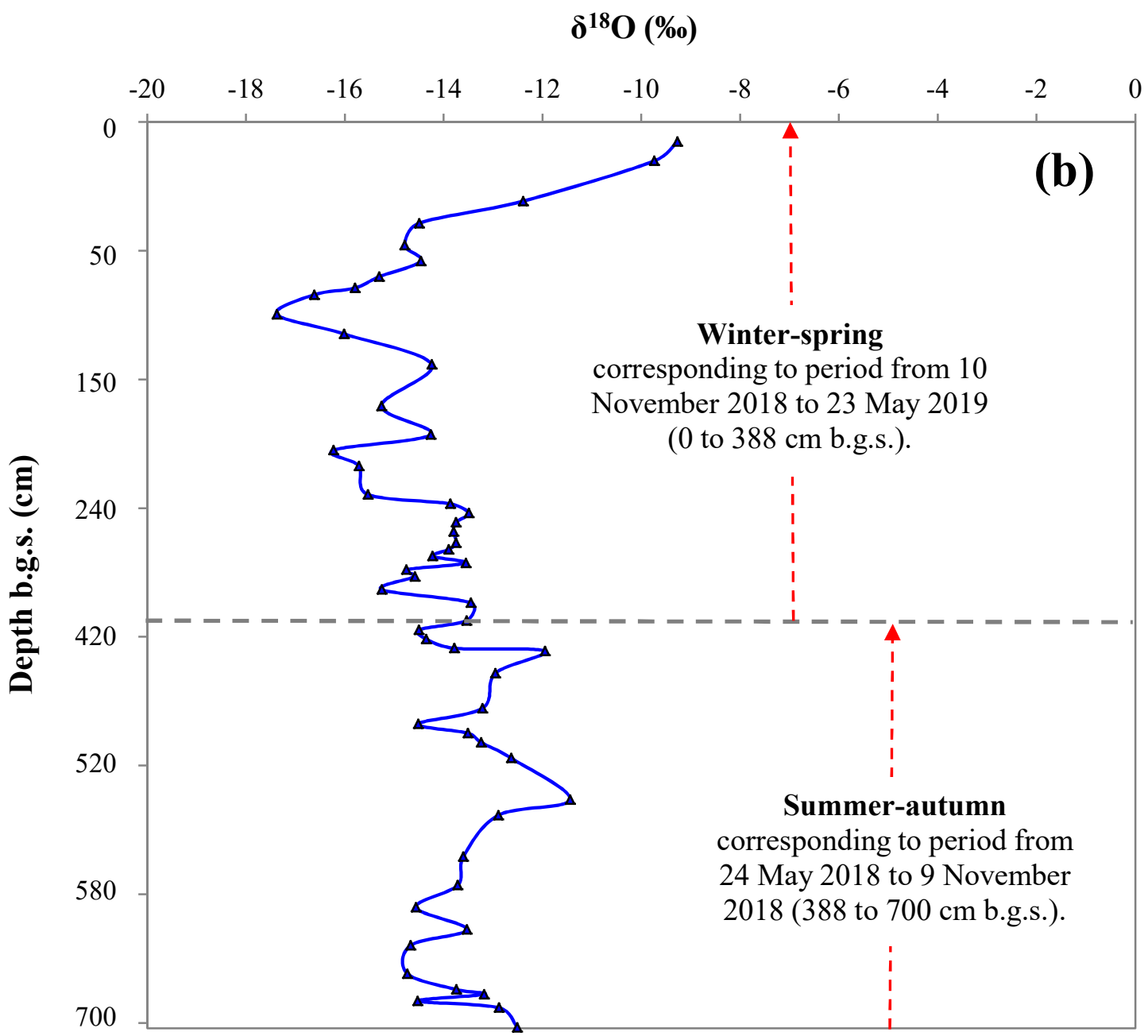

Figure 4. Vadose-zone profiles of $\delta^{18} \mathrm{O}$ determined at (a) Site $\mathrm{S} 1$ and (b) Site S2. The arrows of dotted lines are oriented from the beginning to the end of the studied time periods.

The $\delta^{18} \mathrm{O}$ ratios varied from $-14.67 \%$ to $-8.02 \%$ at Site S1 (Figure $4 \mathrm{a}$ ) and from $-17.38 \%$ to 9.27\% at Site S2 (Figure 4b). Although there was some small-scale variability, the average values in the deeper part of the profile had higher isotope ratios than the overlying portion. The depth of the winter-spring interval differed for S1 and S2 (Figure 4). In order to present similar vadose-zone stable isotope profile for sites S1 and S2, the vertical axes are adjusted using different scaling (right-hand scale for S2 and left-hand scale for S1 in Figure 5). In this way, the 
timings of water percolation can be compared, and it is possible to observe the difference in flow velocity of water having the same isotope value at both sites.

From ground surface to a depth of approximately $150 \mathrm{~cm}$, percolation was similar for both profiles (Figure 5). From $150 \mathrm{~cm}$ downwards, percolation occurred faster at S2 (water traveled $270 \mathrm{~cm}$ from depths $150-420 \mathrm{~cm}$ ) than at S1 (water traveled $170 \mathrm{~cm}$ from depths $140-310 \mathrm{~cm}$ ). The boundary separating the winter-spring from summer-autumn periods occurred at $290 \mathrm{~cm}$ b.g.s. at $\mathrm{S} 1$ and $388 \mathrm{~cm}$ b.g.s. at $\mathrm{S} 2$. At $\mathrm{S} 2$, water flow velocity was 1.3 times greater than at $\mathrm{S} 1$, causing the lower boundary of the winter-spring interval to be deeper than at S1 (For the two depth intervals, the right-hand scale representing S2 is 1.3 times greater than the left-hand scale representing S1 - Figure 5.) During the summer-autumn period, however, water flow velocity was 1.3 times greater at S1 than S2 (Figure 5); water traveled $410 \mathrm{~cm}(290 \mathrm{~cm}$ to $700 \mathrm{~cm})$ at S1, whereas it traveled $312 \mathrm{~cm}$ at S2 (from $388 \mathrm{~cm}$ to $700 \mathrm{~cm}$ ). 


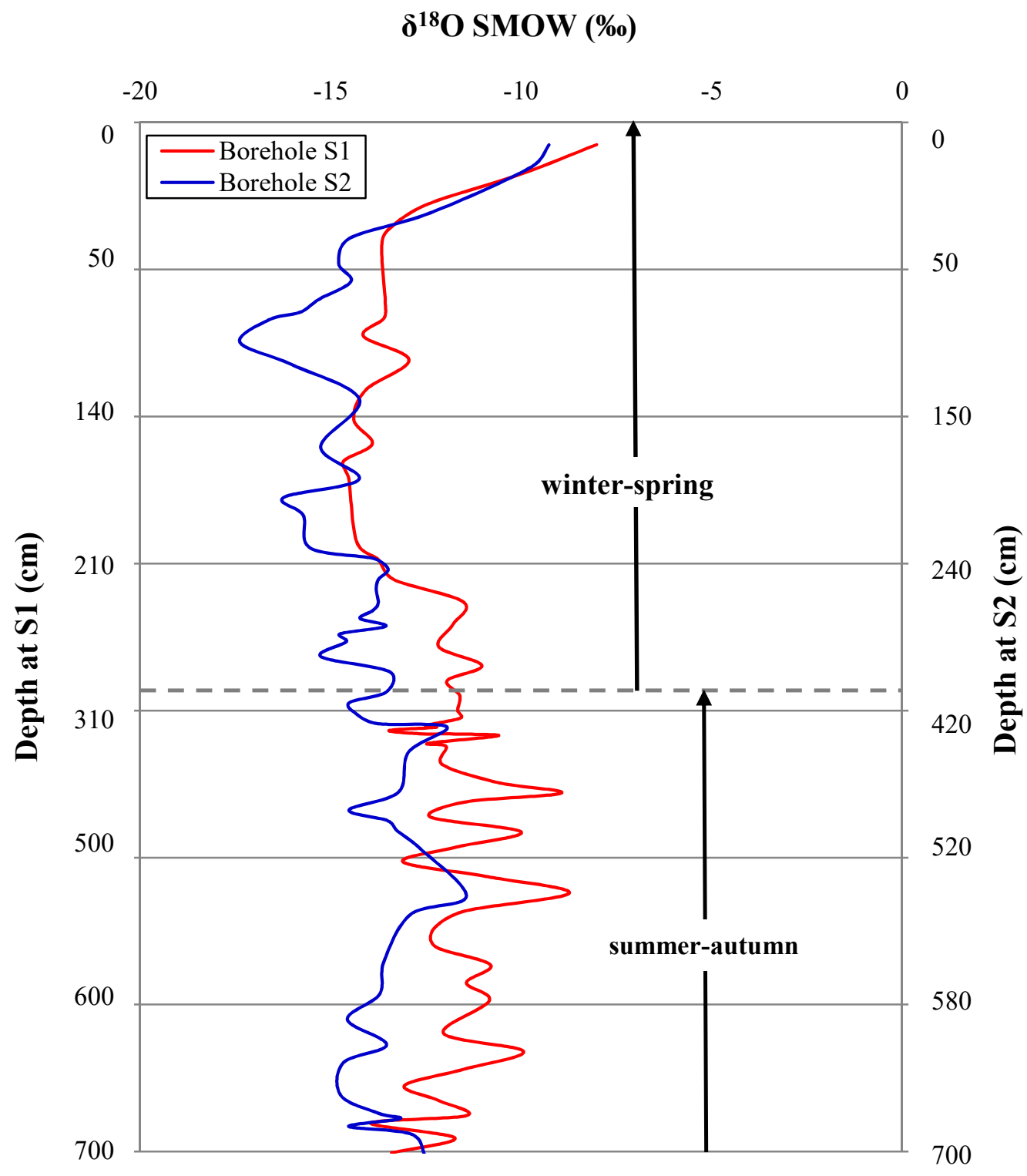

Figure 5. Superposed vadose-zone profiles of $\delta^{18} \mathrm{O}$ determined at sites $\mathrm{S} 1$ and $\mathrm{S} 2$ with differing vertical axis scales; left axis for $\mathrm{S} 1$ and right axis for $\mathrm{S} 2$.

\subsection{Volumetric water content profiles}

The vadose-zone $\theta_{\mathrm{V}}$ profiles for sites $\mathrm{S} 1$ and $\mathrm{S} 2$ - the profiles use two different vertical scales, as in Figure 5 - illustrate a good agreement between the sites (Figure 6). Based on the previously studied periods of water percolation (Figures 4 and 5), a correspondence between the $\theta_{\mathrm{V}}$ profiles and the percolation periods is established. Pore water from the ground surface to $290 \mathrm{~cm} \mathrm{b.g.s.} \mathrm{at}$ 
Site S1 and from the ground surface to $388 \mathrm{~cm}$ b.g.s. at Site $\mathrm{S} 2$ corresponded to the winter-spring period (Figure 5). During this period, at both sites, the pore water between 0 and $40 \mathrm{~cm}$ b.g.s. corresponded to water that had infiltrated from the onset of snowmelt to the sampling day; high values of $\theta_{\mathrm{V}}$ were observed. Below the depth of $40 \mathrm{~cm}$, at both $\mathrm{S} 1$ and $\mathrm{S} 2$, the $\theta_{\mathrm{V}}$ was approximately $7 \%$ and lacked marked variations (Figure 6). Given these low values of $\theta_{\mathrm{V}}$, pore water can be assumed to be in equilibrium in this portion of the zone. The snowpack before the melt and the frozen surface soil combine to act as a barrier to water percolation. This observation can be combined with the vadose-zone stable isotope profile, where the $\delta^{18} \mathrm{O}$ ratios from $40 \mathrm{~cm}$ down to the boundary between the two seasonal periods did not show significant variation (Figure 5). This confirmed that water content at these depths was rather stable. Pore water profiles between 290 and $700 \mathrm{~cm}$ b.g.s. at Site S1 and between 388 and $700 \mathrm{~cm}$ b.g.s. at Site S2 correspond to summer-autumn infiltration (Figure 5). At both sites, the $\theta_{\mathrm{V}}$ varied from 2 to $27 \%$ during this period (Figure 6). The high variability of $\theta_{\mathrm{V}}$ may relate to the various water percolation events during the summer-autumn. This variability is controlled mainly by water percolation that followed the various precipitation events that occurred during the summer and autumn of 2018 . 


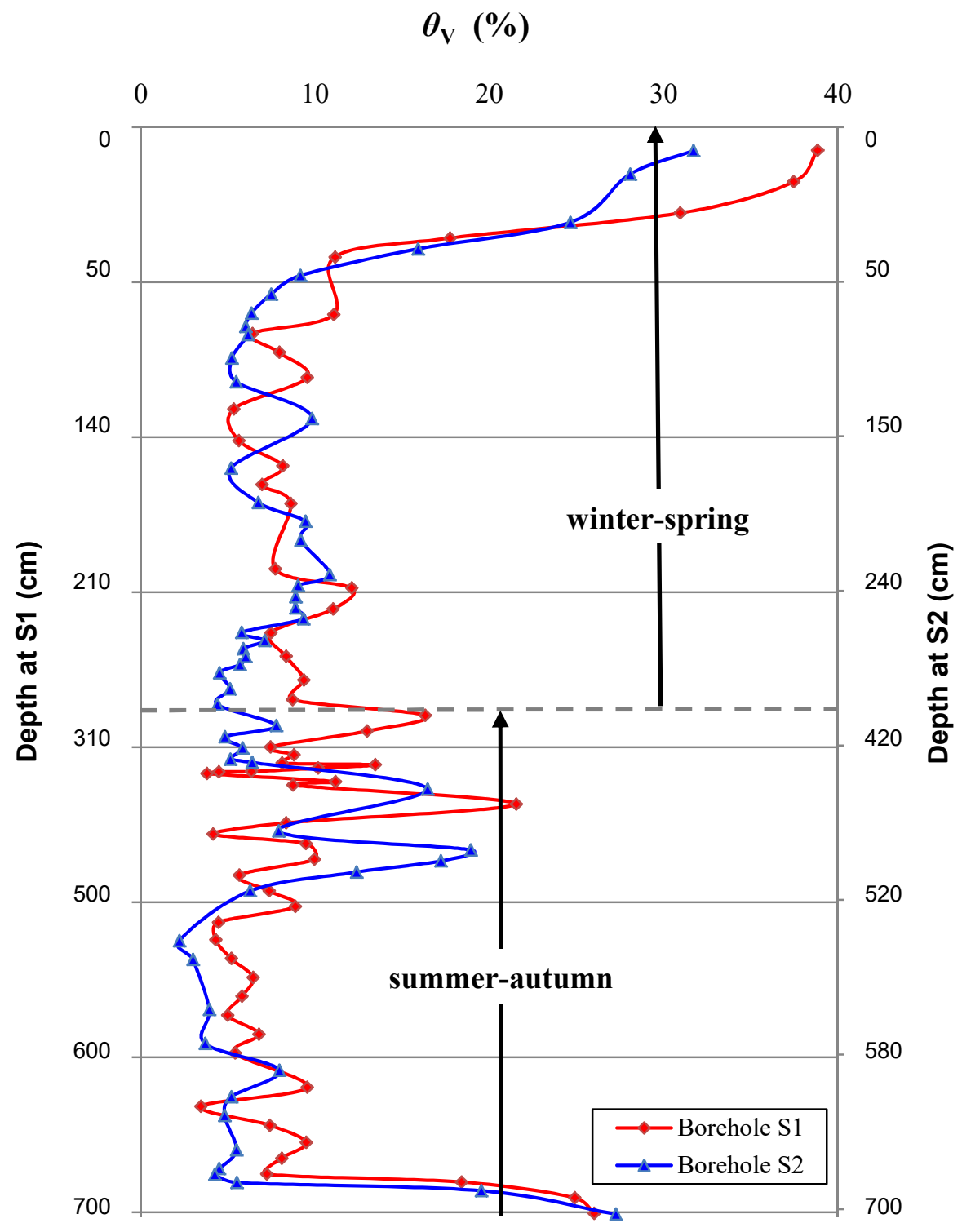

Figure 6. Vadose-zone profiles of $\theta_{\mathrm{V}}$ at sites $\mathrm{S} 1$ and $\mathrm{S} 2$. The profiles are represented using the modified axis scales of Figure 5.

\subsection{Climate data and water flow velocity}

Figure 7 summarizes a one-year history of water percolation within the vadose-zones of S1 and $\mathrm{S} 2$ ( $\mathrm{S} 1$ is presented in Figure $7 \mathrm{a}$, and $\mathrm{S} 2$ is presented in Figure $7 \mathrm{~b}$ ). Combining precipitation, $\theta_{\mathrm{V}}$, vadose-zone depth, and time (one year), the chronological relationship between the pore water profile and its origins could be established. The plotted daily precipitation covers 365 days prior 
to the sampling day. This precipitation represents rainfall and/or snowmelt, where snowmelt was converted into a water equivalent (corrected precipitation). The ratio used for this conversion is the standard 10:1 rule of thumb that converts a value of $1 \mathrm{~cm}$ of snow on the ground to $1 \mathrm{~mm}$ of liquid precipitation (Potter 1965). The total amount of snow falling over the winter season was converted to a water equivalent and then this amount is distributed equally over the end of the winter-spring (after 6 April 2019). This converted water amount was then added to any daily rainfall recorded for these dates. The minor amounts of snowfall in late winter-spring period (Government of Canada 2019) are converted at a daily scale and added to the daily winter-spring rainfall.

There was good agreement between $\theta_{\mathrm{V}}$ and the corrected precipitation profiles at both sites S1 (Figure 7a) and S2 (Figure 7b). A high $\theta_{\mathrm{V}}$ was recorded for the later part of the winter-spring period - during which there is intense precipitation from rainfall combined with snowmelt. A similar observation was noted in the later part of the summer-autumn period, when precipitation is dominated mostly by rainfall combined with some snow (in water equivalent). This late summer-autumn portion represented approximately 45 days before 10 November 2018, which corresponds to the boundary between the two periods. Zones of low $\theta_{\mathrm{V}}$ generally corresponded to periods of low precipitation. This was clearly observed at the start of the winter-spring period, when low water percolation occurred due to the presence of frozen soil. This low $\theta_{\mathrm{V}}$ was also observed during the summer (241 to 334 days before 23 May 2019; Figure 7) when precipitation was occurring only as rainfall (Government of Canada 2019). The good agreement between $\theta_{\mathrm{V}}$ and the corrected precipitation profiles, combined with the timing of water percolation (Figure 7), confirms the established findings from the vadose-zone water isotope ratios and the pore water analyses (sections 'Vadose-zone stable isotope profiles' and 'Volumetric water content profiles'). 
Taking into consideration the duration of the winter-spring and summer-autumn periods, combined with the depth of each period (Figures 4-6), the average water flow velocity was calculated for each of the periods. During the winter-spring period, water percolated downward $290 \mathrm{~cm}$ over 194 days (10 November 2018, to 22 May 2019) at Site S1 and $388 \mathrm{~cm}$ over 195 days (10 November 2018 to 23 May 2019) at Site S2. Accordingly, the average water flow velocity was $1.5 \mathrm{~cm} /$ day $(0.015 \mathrm{~m} / \mathrm{d})$ at Site $\mathrm{S} 1$ and $2 \mathrm{~cm} /$ day $(0.02 \mathrm{~m} / \mathrm{d})$ at Site $\mathrm{S} 2$. For the summer-autumn period, the water was contained within 410 -cm-thick (290-700 cm b.g.s.) and 312-cm-thick (388-700 cm b.g.s.) sections at S1 and S2, respectively. The percolating water traveled through the 410-cm-thick section over 171 days (23 May 2018 to 9 November 2018) and took 170 days to percolate through the 312-cm-thick section (24 May 2018 to 9 November 2018). Accordingly, the calculated water flow velocity at S1 was $2.3 \mathrm{~cm} /$ day $(0.023 \mathrm{~m} / \mathrm{d})$ and at S2 it was $1.8 \mathrm{~cm} /$ day $(0.018 \mathrm{~m} /$ day $)$ during the summer-autumn period. The mean water flow velocity over one year was $1.9 \mathrm{~cm} /$ day $(0.019 \mathrm{~m} / \mathrm{d})$ at both sites $\mathrm{S} 1$ and $\mathrm{S} 2$. 


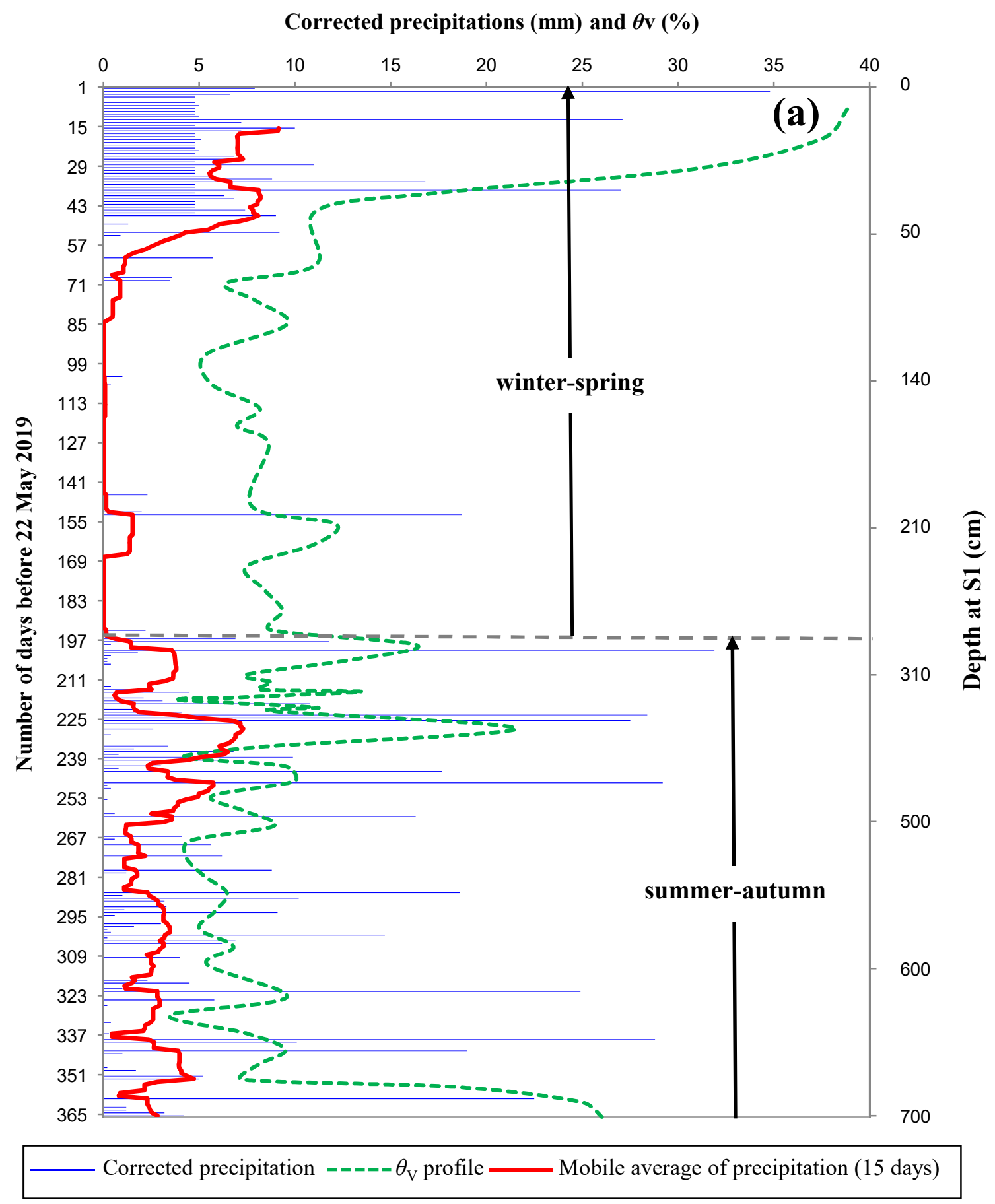




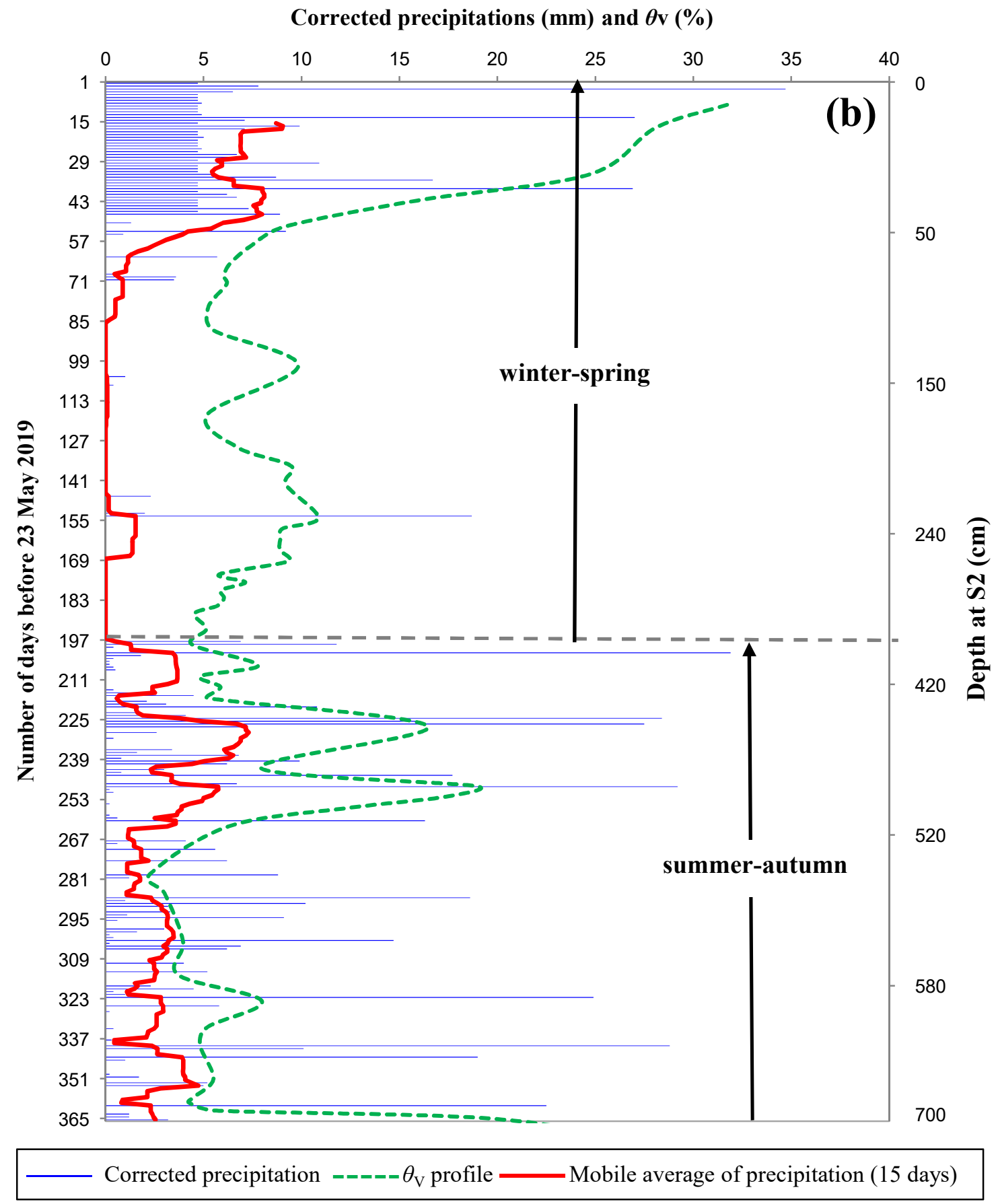

Figure 7. $\theta_{\mathrm{V}}$ vadose-zone profile and corrected precipitation at (a) Site S1 and (b) Site S2. 


\subsection{Hydraulic properties of the study sites}

To verify the findings previously established from the stable isotopes, the water content profiles, and the water flow velocities, we analyzed the soil hydraulic properties of the two vadose-zones at sites S1 and S2. This analysis was performed over different homogeneous time intervals. For Site S1, nine different consecutive intervals were identified, while eight intervals were used for Site S2.

Grain-size sieve analysis (Figure 8; Table 2) revealed that both S1 and S2 were generally composed of gravelly sand containing traces of silt, based on Wentworth's classification (Wentworth 1922). From the grain-size curves (Figure 8) and the soil properties (porosity and void ratio) determined by drying analyses (summarized in Table 2), the average $K_{\mathrm{s}}$ value was calculated for each interval depth at both sites, using the five empirical methods described in Table 1. An average $K_{\text {s.eq }}$ was then calculated to represent each interval that corresponded to either the summer-autumn or winter-spring period. 

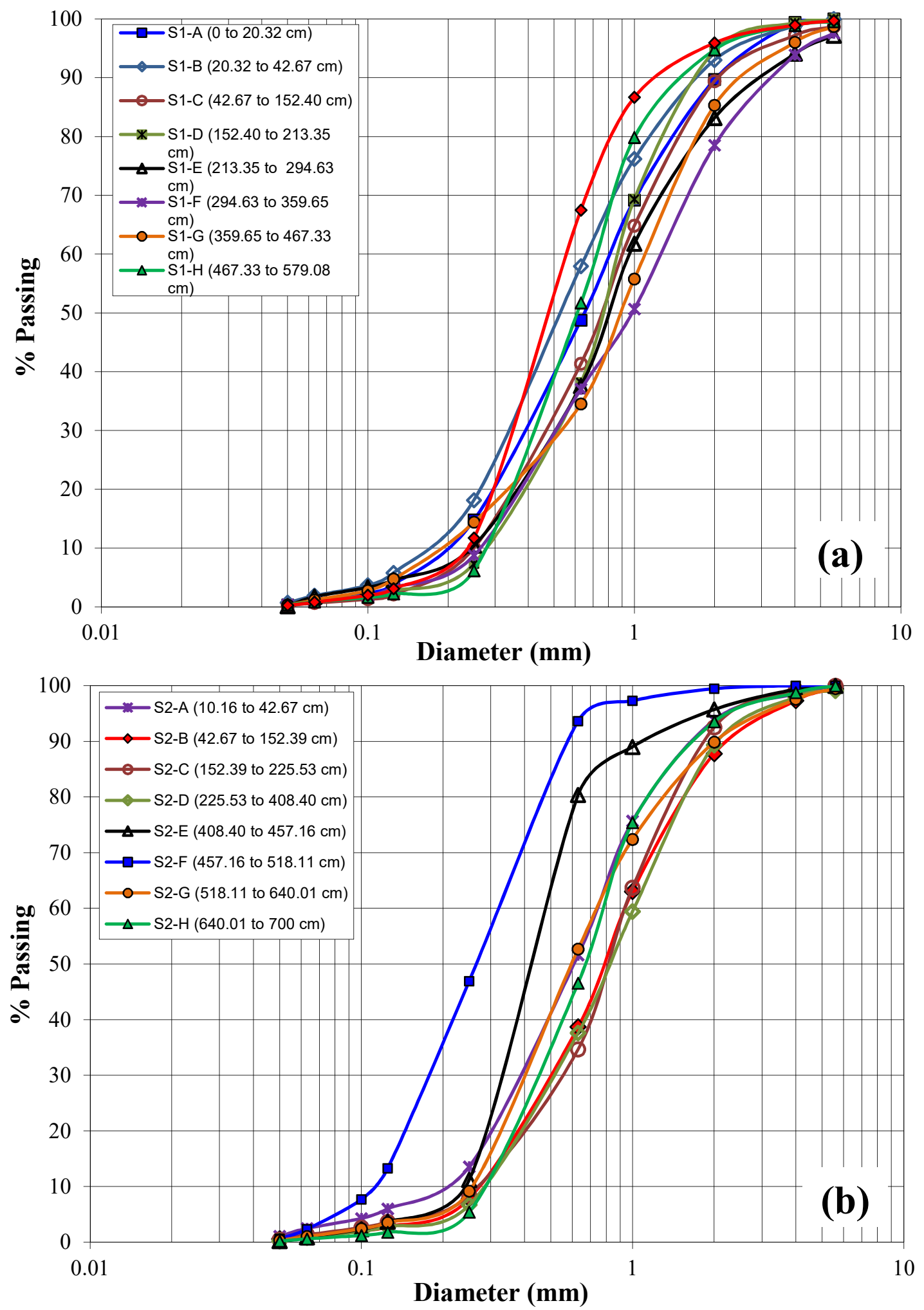

Figure 8. Grain-passing percentages versus sieve-opening diameter for samples collected from (a) Site S1 and (b) Site S2. 
Table 2. Soil characteristics determined from grain-size curves and soil-drying analyses.

\begin{tabular}{|c|c|c|c|c|c|c|c|c|c|c|c|c|c|}
\hline Hole & $\begin{array}{c}\text { Sample } \\
\text { ID }^{a}\end{array}$ & $\begin{array}{l}\text { Depth b.g.s. } \\
\text { interval }(\mathrm{cm})\end{array}$ & $\begin{array}{c}d_{10} \\
(\mathrm{~mm})\end{array}$ & $\begin{array}{c}d_{17} \\
(\mathrm{~mm})\end{array}$ & $\begin{array}{c}d_{20} \\
(\mathrm{~mm})\end{array}$ & $\begin{array}{c}d_{50} \\
(\mathrm{~mm})\end{array}$ & $\begin{array}{c}d_{60} \\
(\mathrm{~mm})\end{array}$ & $\begin{array}{l}C_{\mathrm{u}} \\
(-)\end{array}$ & $\begin{array}{c}n \\
(-)\end{array}$ & $\begin{array}{l}e \\
(-)\end{array}$ & $\begin{array}{c}\text { Average } K_{\mathrm{s}} \\
(\mathrm{cm} / \mathrm{s})\end{array}$ & $\begin{array}{c}\text { Average } \\
K_{\text {s.eq }}(\mathrm{cm} / \mathrm{s})\end{array}$ & $\begin{array}{c}\text { Total average } \\
K_{\text {s.eq }}(\mathrm{cm} / \mathrm{s})\end{array}$ \\
\hline \multirow[t]{9}{*}{ S1 } & S1-A & $00.00-20.32$ & 0.200 & 0.270 & 0.300 & 0.650 & 0.800 & 4.00 & 0.79 & 3.76 & $9.1 \mathrm{E}-02$ & \multirow[t]{5}{*}{$6.6 \mathrm{E}-02$} & \multirow[t]{9}{*}{$6.4 \mathrm{E}-02$} \\
\hline & S1-B & $20.32-42.67$ & 0.180 & 0.240 & 0.270 & 0.520 & 0.680 & 3.78 & 0.61 & 1.56 & $4.4 \mathrm{E}-02$ & & \\
\hline & S1-C & $42.67-152.4$ & 0.250 & 0.310 & 0.360 & 0.750 & 0.900 & 3.60 & 0.49 & 0.96 & $7.3 \mathrm{E}-02$ & & \\
\hline & S1-D & $152.4-213.35$ & 0.280 & 0.350 & 0.390 & 0.760 & 0.880 & 3.14 & 0.47 & 0.89 & $8.4 \mathrm{E}-02$ & & \\
\hline & S1-E & $213.35-294.63$ & 0.250 & 0.320 & 0.370 & 0.800 & 0.950 & 3.80 & 0.43 & 0.75 & $6.0 \mathrm{E}-02$ & & \\
\hline & S1-F & $294.63-359.65$ & 0.270 & 0.330 & 0.380 & 1.000 & 1.400 & 5.19 & 0.43 & 0.75 & $7.6 \mathrm{E}-02$ & \multirow[t]{4}{*}{$6.2 \mathrm{E}-02$} & \\
\hline & S1-G & $359.65-467.33$ & 0.200 & 0.280 & 0.340 & 0.900 & 1.150 & 5.75 & 0.43 & 0.75 & $4.8 \mathrm{E}-02$ & & \\
\hline & $\mathrm{S} 1-\mathrm{H}$ & $467.33-579.08$ & 0.280 & 0.310 & 0.350 & 0.600 & 0.710 & 2.54 & 0.46 & 0.85 & $7.4 \mathrm{E}-02$ & & \\
\hline & S1-I & $579.08-700$ & 0.250 & 0.280 & 0.300 & 0.490 & 0.550 & 2.20 & 0.46 & 0.85 & $5.9 \mathrm{E}-02$ & & \\
\hline \multirow[t]{8}{*}{$\mathrm{S} 2$} & S2-A & $00.00-42.67$ & 0.210 & 0.270 & 0.300 & 0.600 & 0.750 & 3.57 & 0.67 & 2.03 & $6.7 \mathrm{E}-02$ & \multirow[t]{4}{*}{ 7.7E-02 } & \multirow[t]{8}{*}{$4.5 \mathrm{E}-02$} \\
\hline & S2-B & $42.67-152.39$ & 0.280 & 0.360 & 0.380 & 0.800 & 0.950 & 3.39 & 0.47 & 0.89 & $8.4 \mathrm{E}-02$ & & \\
\hline & S2-C & $152.39-225.53$ & 0.280 & 0.360 & 0.380 & 0.800 & 0.950 & 3.39 & 0.47 & 0.89 & $8.4 \mathrm{E}-02$ & & \\
\hline & S2-D & $225.53-408.4$ & 0.280 & 0.360 & 0.380 & 0.800 & 1.000 & 3.57 & 0.44 & 0.79 & $7.5 \mathrm{E}-02$ & & \\
\hline & S2-E & $408.4-457.16$ & 0.250 & 0.270 & 0.290 & 0.420 & 0.490 & 1.96 & 0.48 & 0.92 & $6.2 \mathrm{E}-02$ & \multirow[t]{4}{*}{$3.2 \mathrm{E}-02$} & \\
\hline & S2-F & $457.16-518.11$ & 0.120 & 0.140 & 0.150 & 0.270 & 0.320 & 2.67 & 0.51 & 1.04 & $1.3 \mathrm{E}-02$ & & \\
\hline & S2-G & $518.11-640.01$ & 0.260 & 0.310 & 0.340 & 0.600 & 0.750 & 2.88 & 0.44 & 0.79 & $6.2 \mathrm{E}-02$ & & \\
\hline & $\mathrm{S} 2-\mathrm{H}$ & $640.01-700.97$ & 0.280 & 0.360 & 0.380 & 0.800 & 0.950 & 3.39 & 0.45 & 0.82 & $7.8 \mathrm{E}-02$ & & \\
\hline
\end{tabular}

a: Example: Sample S1-D regroups five soil subsamples collected successively from $152.4 \mathrm{~cm}$ to $213.35 \mathrm{~cm} \mathrm{b.g.s.}$ 
According to Table 2 , the $K_{\text {s.eq }}$ values for the winter-spring interval at site $\mathrm{S} 1$ ( $K_{\text {s.eq }}$ of soil samples S1-A to S1-E) and Site S2 ( $K_{\text {s.eq }}$ of soil samples S2-A to S2-D) were $6.6 \times 10^{-2}$ $\mathrm{cm} / \mathrm{s}$ and $7.7 \times 10^{-2} \mathrm{~cm} / \mathrm{s}$, respectively. The $K_{\text {s.eq }}$ value of Site S2 appeared slightly higher than that of Site S1 and therefore confirmed the difference in the estimated water flow velocity of the winter-spring period (water flow velocity at S2 is faster than at S1). On the other hand, $K_{\text {s.eq }}$ values for the summer-autumn interval at site $\mathrm{S} 1$ ( $K_{\text {s.eq }}$ of soil samples S1-F to S1-I) and Site S2 $\left(K_{\text {s.eq }}\right.$ of soil samples S2-E to S2-H) were $6.2 \times 10^{-2}$ $\mathrm{cm} / \mathrm{s}$ and $3.2 \times 10^{-2} \mathrm{~cm} / \mathrm{s}$, respectively. The $K_{\mathrm{s} . \text { eq }}$ value of S2 appeared slightly lower than that of site S1 and therefore confirmed the previous findings where the water flow velocity during summer-autumn was determined to be slightly faster at S1 compared to $\mathrm{S} 2$. Despite the slight difference between the total average $K_{\text {s.eq }}$ values at Site $\mathrm{S} 1(6.4 \times$ $\left.10^{-2} \mathrm{~cm} / \mathrm{s}\right)$ and S2 $\left(4.5 \times 10^{-2} \mathrm{~cm} / \mathrm{s}\right)$, the values were of the same magnitude. This could explain the similar total mean water flow velocity, where the same water flow velocity $(1.9 \mathrm{~cm} /$ day) over one year was determined for both sites $\mathrm{S} 1$ and $\mathrm{S} 2$.

\subsection{Possible groundwater recharge and transpiration}

Figure 7 and eqn. (8) were used to calculate possible groundwater recharge at sites S1 and S2 during the winter-spring and summer-autumn periods (Table 3 ). The $\theta_{\mathrm{r}}$ value of eqn. (8) was assumed to be constant at both study sites. A value of $1 \%$, based on the results presented in Figure 6a, was applied. 
Table 3. Possible groundwater recharge values calculated at S1 and S2 for the considered periods.

\begin{tabular}{|c|c|c|c|}
\hline \multirow{2}{*}{ Site } & \multirow{2}{*}{ Parameter } & \multicolumn{2}{|c|}{ Period } \\
\cline { 3 - 4 } & & Winter-spring & Summer-autumn \\
\hline \multirow{4}{*}{ S1 } & Corresponding dates & 10 November 2018 to 22 May 22 2019 & 24 May 2018 to 9 November 2018 \\
\cline { 2 - 4 } & Precipitation (mm) & 400 & 524 \\
\cline { 2 - 4 } & Recharge (mm) & 284 & 332 \\
\cline { 2 - 4 } & Recharge (\%) & 71 & 63 \\
\hline \multirow{4}{*}{ S2 } & Corresponding dates & 10 November 2018 to 23 May 2019 & 24 May 2018 to 9 November 2018 \\
\cline { 2 - 4 } & Precipitation (mm) & 399 & 521 \\
\cline { 2 - 4 } & Recharge (mm) & 299 & 215 \\
\cline { 2 - 4 } & Recharge (\%) & 75 & 41 \\
\hline
\end{tabular}

In the winter-spring period, the calculated possible groundwater recharge at Site S1 was $284 \mathrm{~mm}$, with a total precipitation of $400 \mathrm{~mm}$ (snowmelt plus rainfall); therefore, the possible groundwater recharge rate was $71 \%$ from precipitation during this period. The calculated possible groundwater recharge at Site S2 was $299 \mathrm{~mm}$ during the same time period. With a total precipitation of $399 \mathrm{~mm}$ received during this period, the calculated possible groundwater recharge rate at S2 represented $75 \%$ of the precipitation. During the summer-autumn period, the calculated possible groundwater recharge at Site S1 was 332 $\mathrm{mm}$, representing $63 \%$ of the total precipitation received during this period $(524 \mathrm{~mm})$. At Site $\mathrm{S} 2$, the possible groundwater recharge rate was $41 \%$, representing a possible groundwater recharge of $215 \mathrm{~mm}$ based on a total precipitation of $521 \mathrm{~mm}$. The sites S1 and S2 are both located in a flat area (runoff can be neglected), and both sites receive very similar amounts of precipitation (Table 3).

As sites S1 and S2 have similar textures and soil characteristics - except for the presence of pine trees at S2 - differences between the possible groundwater recharge at sites S1 and S2 could therefore be attributed to a possible difference in the evapotranspiration 
rate, dominated by transpiration through pine trees at Site S2. Only transpiration for summer-autumn period is considered because the root system of pine trees is not effective at taking up water during the winter-spring period. Moreover, the presence of a snowpack combined with frozen surface soil during the winter-spring period limits evaporation. As the two study sites are covered by vegetation, the rate of evaporation will be lower due to lower soil temperatures and a more limited movement of water vapor (Benoit and Kirkham 1963; Shah et al. 2007). The possible groundwater recharge rates calculated at sites S1 and S2 were $63 \%$ and $41 \%$, respectively. The possible transpiration rate of the pine trees therefore represented the $22 \%$ difference; these rates reflected a difference between the possible groundwater recharge at S1 $(332 \mathrm{~mm})$ and S2 $(215 \mathrm{~mm})$ relative to the mean precipitation amount recorded during the summer-autumn period at both sites $(523 \mathrm{~mm})$. Compared to other studies in nearby regions (Tremblay 2005; Huet et al. 2016; Chesnaux and Stumpp 2018), a possible groundwater recharge rate of $41 \%$ is similar to that expected during the summer for the Saint-Honore aquifer composed of sand with silt (Boumaiza 2008). However, a possible groundwater recharge rate of $63 \%$ obtained for Site S1 seems high, but this level of possible groundwater recharge can still be accurate, given the limited transpiration at Site S1 and lack of vegetation coverage by dense trees. It should be mentioned that any knowledge about the possible presence of previously infiltrated water of a different origin in the soil pores prior to the periods identified in the soil profiles remains difficult to determine. Such water may be present in the form of residual water in the soil pores, and would contribute to the variability observed in the isotopic data. It could therefore be useful to sample water in different soil pores to extract fingerprint information revealing the presence of "old, more tightly 
bound" water. Variability in the isotopic data can also be associated with water displacement by dispersion, a factor which is not taken into consideration by the peakshift method, which assumes advection-dominated transport. Because the vadose-zone is usually heterogeneous in texture, a portion of the flow within the unsaturated zone could be lateral, leading to an underestimation of recharge. To counter this limitation, it might be useful to investigate the dispersion process by conducting high-resolution soil sampling in vertical and horizontal orientations. Recalling that this study was conducted using periodic (monthly) stable isotope precipitation data, one may imagine that more intense monitoring of precipitation data, including multiple stable isotope measurements, might improve our understanding of the relationship that exists between specific instances of variability in soil profiles and specific meteorological events.

Results from independent studies at three sites in the western USA, where vegetation was the primary control of water balance, testify to the relative influence of plants in reducing possible groundwater recharge (Gee et al. 1994). In their review of case studies focused on possible groundwater recharge estimates throughout Australia, Petheram et al. (2002) divided the land use of the case studies into three general categories: (i) annuals (shallowrooted annual crops or pasture), (ii) perennials (perennial pastures and native herbaceous vegetation), and (iii) trees (very deep-rooted vegetation). The results of the collated possible groundwater recharge studies confirm that the possible groundwater recharge is higher under shallow-rooted annual vegetation than under deep-rooted vegetation. In the present study, a possible transpiration rate of $22 \%$ for the pine trees during the summerautumn period represented the difference in possible groundwater recharge between sites $\mathrm{S} 1(332 \mathrm{~mm})$ and $\mathrm{S} 2(215 \mathrm{~mm})$ relative to the total days considered for the summer- 
autumn period (170 days - Table 3). Consequently, the mean daily possible transpiration rate was $0.7 \mathrm{~mm} /$ day. This value agrees with rates estimated by other studies. An identical transpiration rate $(0.7 \mathrm{~mm} /$ day $)$ was found in a study of a mixed old stand of sub-boreal forest in central Sweden having a climate comparable to that of Eastern

Quebec, based on direct measurement of 24 large Scots pine and Norway spruce (Čermák et al. 1995). In another study, Zmermann et al. (2000) determined an average transpiration rate of $0.72 \pm 0.3 \mathrm{~mm} /$ day for all age classes within stands of a central Siberian pine forest.

\section{CONCLUSIONS AND FURTHER RESEARCH}

In the present study, the down-core profiles of stable isotopes of pore water were analyzed, soil water content was measured and the hydraulic properties of the collected soil samples were determined. The 7-m-thick vadose-zones at both study sites (S1 and S2) held the full stable isotope profile of the vadose-zone over one year and, consequently, provided complete information related to the possible groundwater recharge during the different periods of percolation. During the winter-spring period, there was no significant difference in possible groundwater recharge between sites S1 (71\%) and S2 (75\%). This lack of difference was explained by the negligible evapotranspiration rate at both sites when the surface soil was frozen and snowmelt was negligible. Moreover, the root system of pine trees at site S2 was not effective at taking up water during the winter-spring period, and consequently, the transpiration process was limited. During the summer-autumn period, a possible groundwater recharge rate of $63 \%$ was obtained for Site S1, while that for Site S2 was $41 \%$. The possible groundwater 
recharge rate was higher at Site S1 than at Site S2 because transpiration at Site S1 is limited compared to Site S2. Indeed, Site S1 is covered with herbaceous vegetation whereas Site S2 presents a dense coverage of mature pine trees. The mean daily possible transpiration rate for the pine trees in the present study was determined to be $0.7 \mathrm{~mm} / \mathrm{day}$. This value agrees with values determined in other studies conducted in comparable climates. The results of this study are in line with previous studies confirming the utility of the peak-shift method for assessing possible groundwater recharge and the transpiration rate of forested sites.

The pronounced seasonal differences observed in the isotopic signatures of rain water make it possible to employ isotopic analysis to distinguish the different periods of water percolation in the vadose-zone, and this distinction makes it possible to measure recharge. However, in regions where seasonal differences are less pronounced, the absence of a clear distinction of seasonal precipitations would likely limit the applicability of the peak-shift method. Future research efforts in the field of recharge estimates using the peak-shift method could focus on determining the limits of its applicability for assessing recharge and evapotranspiration in regions and climates other than humid northern, such as semi-arid or arid regions.

\section{ACKNOWLEDGMENTS}

This study was conducted in the framework of an international research collaboration between the Université du Québec à Chicoutimi (Quebec) in Canada and the University of Natural Resources and Life Sciences (Vienna) in Austria. The first author benefited from the Mitacs Globalink Research Program (Canada) to conduct an internship of four months at the University of Natural Resources and Life Sciences (Vienna-Austria). The 
authors thank Mitacs for this financial support and also acknowledge the financial support of other organizations of the Université du Québec à Chicoutimi, namely the Bureau de l'International, Service de la Vie Étudiante, MAGE-UQAC, and the Décanat de la recherche et de la création. The authors thank Professor Florent Barbecot (GEOTOP Laboratory of the Université du Québec à Montréal - Canada) for providing water isotope monitoring data from the UQAC station. David Noël is thanked for help with the core soil sampling in Quebec. Martina Faulhammer and Andrea Fuchs are thanked for their help with the stable isotope measurements in Vienna.

\section{APPENDIX: ABBREVIATIONS AND SYMBOLS}

b.g.s.: below ground surface

$K_{\mathrm{s}}$ : saturated hydraulic conductivity $(\mathrm{cm} / \mathrm{s})$

$K_{\text {s.eq: }}$ equivalent saturated hydraulic conductivity $(\mathrm{cm} / \mathrm{s})$

$K$ : unsaturated hydraulic conductivity $(\mathrm{cm} / \mathrm{s})$

$\theta_{\mathrm{V}}$ : volumetric water content $\left(\mathrm{cm}^{3} / \mathrm{cm}^{3}\right)$

$\theta_{\mathrm{r}}$ : residual volumetric water content $\left(\mathrm{cm}^{3} / \mathrm{cm}^{3}\right)$

\section{REFERENCES}

Adomako D, Maloszewski P, Stumpp C, Osae S, Akiti TT (2010) Estimating groundwater recharge from water isotope $(\delta 2 \mathrm{H}, \delta 18 \mathrm{O})$ depth profiles in the Densu River basin, Ghana. Hydrological Sciences Journal 55:1405-1416.

Allison GB, Gee GW, Tyler SW (1994) Vadose-zone techniques for estimating groundwater recharge in arid and semi-arid regions. Soil Science Society of America Journal 58:6-14.

Anderson MP (1989) Hydrogeologic facies models to delineate large-scale spatial trends in glacial and glaciofluvial sediments. Geological Society of America Bulletin 101:501-511.

Bakker M, Bartholomeus R, Ferre T (2013) Groundwater recharge: processes and quantification. Hydrology and Earth System Sciences 17:2653-2655.

Barbecot F, Guillon S, Pili E, Larocque M, Gibert-Brunet E, Hélie J-F, Noret A, Plain C, Schneider V, Mattei A, Meyzonnat G (2018) Using water stable isotopes in the unsaturated zone to quantify recharge in two contrasted infiltration regimes. Vadose 
Zone Journal 17:1-13.

Benoit GR, Kirkham D (1963) The effect of soil surface conditions on evaporation of soil water1. Soil Science Society of America Journal 27:495-498.

Beyer W (1964) Zur bestimmung der wasserdurchlässigkeit von kiesen und sanden aus der kornverteilungskurve [On determining the water permeability of gravel and sand from the grain distribution curve]. Wasserwirtsch Wassertech 14:165-168.

Black CA, Evans DD, White JL, Ensming LE, Clark FE, Dinaueu RC (1965) Methods of soil analysis, Part 1, Physical and mineralogical properties including staistics of measurement and sampling. American Society Agronomy, Inc Publisher. Madison. Wisconsin USA

Boumaiza L (2008) Caractérisation hydrogéologique des hydrofaciès dans le paléodelta de la rivière Valin au Saguenay [Hydrogeological characterization of hydrofacies in the Valin River Paleodelta in Saguenay]. Master's Thesis, Université du Québec à Chicoutimi, Québec, Canada

Boumaiza L, Rouleau A, Cousineau PA (2015) Estimation of hydraulic conductivity and porosity of the identified lithofacies in the granular deposits of Valin river paleodelta in Saguenay region of Quebec. In: Proceedings of the 68th Canadian Geotechnical Conference, Quebec City, Quebec, Canada. p 9

Boumaiza L, Rouleau A, Cousineau PA (2019) Combining shallow hydrogeological characterization with borehole data for determining hydrofacies in the Valin River paleodelta. In: Proceedings of the 72nd Canadian Geotechnical Conference, StJohn's, Newfoundland, Canada. p 8

Boumaiza L, Rouleau A, Cousineau PA (2017) Determining hydrofacies in granular deposits of the Valin River paleodelta in the Saguenay region of Quebec. In: Proceedings of the 70th Canadian Geotechnical Conference and the 12th Joint CGS/IAH-CNC Groundwater Conference, Ottawa, Ontario, Canada. p 8

Bredehoeft J (2007) It is the discharge. Ground Water 45:523-523.

Cartwright I, Cendón D, Currell M, Meredith K (2017) A review of radioactive isotopes and other residence time tracers in understanding groundwater recharge: Possibilities, challenges, and limitations. Journal of Hydrology 555:797-811.

Čermák J, Cienciala E, Kučera J, Lindroth A, Bednářová E (1995) Individual variation of sap-flow rate in large pine and spruce trees and stand transpiration: a pilot study at the central NOPEX site. Journal of Hydrology 168:17-27.

Chapuis RP (2012) Predicting the saturated hydraulic conductivity of soils: A review. Bulletin of Engineering Geology and the Environment 71:401-434.

Chapuis RP (2004) Predicting the saturated hydraulic conductivity of sand and gravel using effective diameter and void ratio. Canadian Geotechnical Journal 41:787-795.

Chesnaux R (2013) Regional recharge assessment in the crystalline bedrock aquifer of the Kenogami Uplands, Canada. Hydrological Sciences Journal 58:421-436.

Chesnaux R, Santoni S, Garel E, Huneau F (2018) An analytical method for assessing recharge using groundwater travel time in Dupuit-Forchheimer aquifers. Groundwater 56:986-992.

Chesnaux R, Stumpp C (2018) Advantages and challenges of using soil water isotopes to assess groundwater recharge dominated by snowmelt at a field study located in Canada. Hydrological Sciences Journal 63:679-695.

Craig H (1961) Isotopic variations in meteoric waters. Science 133:1702-1703. 
Crawford J, Hughes CE, Parkes SD (2013) Is the isotopic composition of event based precipitation driven by moisture source or synoptic scale weather in the Sydney Basin, Australia? Journal of Hydrology 507:213-226.

Crosbie RS, Binning P, Kalma JD (2005) A time series approach to inferring groundwater recharge using the water table fluctuation method. Water Resources Research 41:1-9.

Crosbie RS, Peeters LJM, Herron N, McVicar TR, Herr A (2018) Estimating groundwater recharge and its associated uncertainty: Use of regression kriging and the chloride mass balance method. Journal of Hydrology 561:1063-1080.

Dansgaard W (1964) Stable isotopes in precipitation. Tellus 16:436-468.

De Vries JJ, Simmers I (2002) Groundwater recharge: An overview of processes and challenges. Hydrogeology Journal 10:5-17.

Doble RC, Crosbie RS (2017) Review: Current and emerging methods for catchmentscale modelling of recharge and evapotranspiration from shallow groundwater. Hydrogeology Journal 25:3-23.

Eaton TT (2006) On the importance of geological heterogeneity for flow simulation. Sedimentary Geology 184:187-201.

Fan J, Oestergaard KT, Guyot A, Lockington DA (2014) Estimating groundwater recharge and evapotranspiration from water table fluctuations under three vegetation covers in a coastal sandy aquifer of subtropical Australia. Journal of Hydrology 519:1120-1129.

Freeze RA, Cherry JA (1979) Groundwater. Prentice Hall, Englewood Cliff

Gardner WH (1965) Water content. In: Black, CA (Ed), Methods of Soil Analysis American Society of Agronomy, Inc, Madison, Wisconsin, USA 82-127.

Gee GW, Wierenga PJ, Andraski BJ, Young MH, Fayer MJ, Rockhold ML (1994) Variations in water balance and recharge potential at three western desert sites. Soil Science Society of America Journal 58:63-72.

Gehrels JC, Peeters JEM, De Vries JJ, Dekkers M (1998) The mechanism of soil water movement as inferred from ${ }^{18} \mathrm{O}$ stable isotope studies. Hydrological Sciences Journal 43:579-594.

Government of Canada (2019) Canada's national climate archive. http://www.climate.weatheroffice.ec.gc.ca/climate_normals/ [consulted in July 2019]

Guan H, Zhang X, Skrzypek G, Sun Z, Xu Xi (2013) Deuterium excess variations of rainfall events in a coastal area of south Australia and its relationship with synoptic weather systems and atmospheric moisture sources. Journal of Geophysical Research Atmospheres 118:1123-1138.

Hazen A (1892) Some physical properties of sand and gravel, with their special reference to their use in filtration. 24th annual report, Boston, Massachusetts State Board of Health 34:539-556.

Hendry MJ, Wassenaar LI (2009) Inferring heterogeneity in aquitards using highresolution $\delta \mathrm{d}$ and $\delta^{18} \mathrm{O}$ profiles. Ground Water 47:639-645.

Huet M, Chesnaux R, Boucher MA, Poirier C (2016) Comparing various approaches for assessing groundwater recharge at a regional scale in the Canadian Shield. Hydrological Sciences Journal 61:2267-2283.

IAEA (International Atomic Energy Agency) (2020) IAEA's scientific, technical and 
regulatory information resources. https://nucleus.iaea.org/Pages/default.aspx

Joshi B, Maulé C (2000) Simple analytical models for interpretation of environmental tracer profiles in the vadose zone. Hydrological Processes 14:1503-1521.

Koeniger P (2003) Tracer hydrological investigations on groundwater recharge. Institut für Hydrologie, Freiburger Schriften zur Hydrologie Nr. 16

Koeniger P, Gaj M, Beyer M, Himmelsbach T (2016) Review on soil water isotope-based groundwater recharge estimations. Hydrological Processes 30:2817-2834.

Kurylyk BL, MacQuarrie KTB (2013) The uncertainty associated with estimating future groundwater recharge: A summary of recent research and an example from a small unconfined aquifer in a northern humid-continental climate. Journal of Hydrology 492:244-253.

Lee $\mathrm{CH}$, Chen WP, Lee RH (2006) Estimation of groundwater recharge using water balance coupled with base-flow-record estimation and stable-base-flow analysis. Environmental Geology 51:73-82.

Leibundgut C, Maloszewski P, Külls C (2009) Tracers in hydrology. John Wiley \& Sons Ltd.

Liu Y, Yamanaka T, Zhou X, Tian F, Ma W (2014) Combined use of tracer approach and numerical simulation to estimate groundwater recharge in an alluvial aquifer system: A case study of Nasunogahara area, central Japan. Journal of Hydrology 519:833847.

McConville C, Kalin RM, Johnston H, McNeill GW (2001) Evaluation of recharge in a small temperate catchment using natural and applied delta ${ }^{18} \mathrm{O}$ profiles in the unsaturated zone. Ground Water 39:616-23.

Memon BA (1995) Quantitative analysis of springs. Environmental Geology 26:111-120.

Mueller MH, Alaoui A, Kuells C, Leistert H, Meusburger K, Stumpp C, Weiler M, Alewell C (2014) Tracking water pathways in steep hillslopes by $\delta 180$ depth profiles of soil water. Journal of Hydrology 519:340-352.

Petheram C, Walker G, Grayson R, Thierfelder T, Zhang L (2002) Towards a framework for predicting impacts of land-use on recharge: 1 . A review of recharge studies in Australia. Australian Journal of Soil Research 40:397-417.

Potter J (1965) Water content of freshly fallen snow. Rep. CIR-4232, TEC-569, Meteorological Branch, Department of Transport, Toronto (Ontario) Canada

Rutledge AT (2007) Update on the use of the RORA program for recharge estimation. Ground Water 45:374-382.

Sauerbrey II (1932) On the problem and determination of the permeability coefficient. VNIIG Proceedings 3-5.

Saxena RK (1987) Oxygen-18 fractionation in nature and estimation of groundwater recharge. Ph.D thesis, Uppsala University, Sweden

Saxena RK, Dressie Z (1984) Estimation of groundwater recharge and moisture movement in sandy formations by tracing natural oxygen-18 and injected tritium profiles in the unsaturated zone. In: International Atomic Energy Agency (IAEA) Proceedings Series 270/46, 12-16 September 1983, International Atomic Energy Agency, Vienna, Austria. pp 139-150. ISBN 92-0-040084-1

Seelheim F (1880) Methoden zur bestimmnng der durchlässigkeit des bodens [Methods for determining the permeability of the soil]. Zeitschrift für Analytische Chemie 19:387-402. 
Shah N, Nachabe M, Ross M (2007) Extinction depth and evapotranspiration from ground water under selected land covers. Ground Water 45:329-338.

Sophocleous MA (1991) Combining the soilwater balance and water-level fluctuation methods to estimate natural groundwater recharge: Practical aspects. Journal of Hydrology 124:229-241.

Stewart MK, McDonnell JJ (1991) Modeling base flow soil water residence times from deuterium concentrations. Water Resources Research 27:2681-2693.

Stumpp C, Hendry MJ (2012) Spatial and temporal dynamics of water flow and solute transport in a heterogeneous glacial till: The application of high-resolution profiles of $\delta^{18} \mathrm{O}$ and $\delta^{2} \mathrm{H}$ in pore waters. Journal of Hydrology 438-439:203-214.

Stumpp C, Maloszewski P, Stichler W, Fank J (2009) Environmental isotope $\left(\delta^{18} \mathrm{O}\right)$ and hydrological data to assess water flow in unsaturated soils planted with different crops: Case study lysimeter station "Wagna" (Austria). Journal of Hydrology 369:198-208.

Stumpp C, Stichler W, Kandolf M, Šimůnek J (2012) Effects of land cover and fertilization method on water flow and solute transport in five lysimeters: A longterm study using stable water isotopes.

Thoma G, Esser N, Sonntag C, Weiss W, Rudolph J, Levene P (1979) New technique of insitu soil moisture sampling for environmental isotope analysis applied at "Pilatdune" near Bordeaux. International symposium on isotope hydrology 753-766 IAEA/UNESCO, Vienna, Austria.

Tremblay P (2005) Étude hydrogéologique de l'aquifère de Saint-Honoré avec emphase sur son bilan hydrique [Hydrogeologic analysis of Saint-Honoré aquifer with emphasis on its water budge]. Master's Thesis, Université du Québec à Chicoutimi, Québec, Canada

Vukovic M, Soro A (1992) Determination of hydraulic conductivity of porous media from grain-size composition. Water Resources Publications, Littleton, Colorado

Wassenaar LI, Hendry MJ, Chostner VL, Lis GP (2008) High resolution pore water $\delta 2 \mathrm{H}$ and $\delta 18 \mathrm{O}$ measurements by $\mathrm{H} 2 \mathrm{O}$ (liquid)-H2O (vapor) equilibration laser spectroscopy. Environmental Science and Technology 42:9262-9267.

Wentworth CK (1922) A scale of grade and class terms for clastic sediments. Journal of Geology 30:507-521.

Yeh HF, Lee CH, Chen JF, Chen WP (2007) Estimation of groundwater recharge using water balance model. Water Resources 34:153-162.

Zappa G, Bersezio R, Felletti F, Giudici M (2006) Modeling heterogeneity of gravelsand, braided stream, alluvial aquifers at the facies scale. Journal of Hydrology 325:134-153.

Zmermann R, Schulze ED, Wirth C, Schulze EE, Mcdonald KC, Vygodskaya NN, Ziegler W (2000) Canopy transpiration in a chronosequence of Central Siberian pine forests. Global Change Biology 6:25-37. 